\title{
Biomass burning influence on high-latitude tropospheric ozone and reactive nitrogen in summer 2008: a multi-model analysis based on POLMIP simulations
}

\author{
S. R. Arnold ${ }^{1}$, L. K. Emmons ${ }^{2}$, S. A. Monks ${ }^{1}$, K. S. Law $^{3}$, D. A. Ridley ${ }^{4}$, S. Turquety ${ }^{5}$, S. Tilmes ${ }^{2}$, J. L. Thomas ${ }^{3}$, \\ I. Bouarar ${ }^{3}$, J. Flemming ${ }^{6}$, V. Huijnen ${ }^{7}$, J. Mao ${ }^{8}$, B. N. Duncan ${ }^{9}$, S. Steenrod ${ }^{9}$, Y. Yoshida ${ }^{9}$, J. Langner ${ }^{10}$, and Y. Long \\ ${ }^{1}$ Institute for Climate and Atmospheric Science, School of Earth \& Environment, University of Leeds, UK \\ ${ }^{2}$ Atmospheric Chemistry Division, NCAR, Boulder, CO, USA \\ ${ }^{3}$ UPMC Univ. Paris 06, Université Versailles St-Quentin; CNRS/INSU, UMR 8190, Paris, France \\ ${ }^{4}$ Department of Civil and Environmental Engineering, Massachusetts Institute of Technology, Cambridge, MA, USA \\ ${ }^{5}$ Laboratoire de Météorologie Dynamique, IPSL, CNRS, UMR8539, 91128 Palaiseau CEDEX, France \\ ${ }^{6}$ ECMWF, Reading, UK \\ ${ }^{7}$ Royal Netherlands Meteorological Institute (KNMI), De Bilt, the Netherlands \\ ${ }^{8}$ Program in Atmospheric and Oceanic Sciences, Princeton University and Geophysical Fluid Dynamics Laboratory/National \\ Oceanic and Atmospheric Administration, Princeton, NJ, USA \\ ${ }^{9}$ NASA Goddard Space Flight Center, Greenbelt, MD, USA \\ ${ }^{10}$ Swedish Meteorological and Hydrological Institute, 60176 Norrköping, Sweden \\ Correspondence to: S. R. Arnold (s.arnold@leeds.ac.uk)
}

Received: 17 July 2014 - Published in Atmos. Chem. Phys. Discuss.: 24 September 2014

Revised: 29 April 2015 - Accepted: 4 May 2015 - Published: 3 June 2015

\begin{abstract}
We have evaluated tropospheric ozone enhancement in air dominated by biomass burning emissions at high latitudes $\left(>50^{\circ} \mathrm{N}\right)$ in July 2008, using 10 global chemical transport model simulations from the POLMIP multimodel comparison exercise. In model air masses dominated by fire emissions, $\Delta \mathrm{O}_{3} / \Delta \mathrm{CO}$ values ranged between 0.039 and $0.196 \mathrm{ppbv} p p b v^{-1}$ (mean: $0.113 \mathrm{ppbv} \mathrm{ppbv}^{-1}$ ) in freshly fire-influenced air, and between 0.140 and $0.261 \mathrm{ppbv} \mathrm{ppbv}^{-1}$ (mean: $0.193 \mathrm{ppbv}$ ) in more aged fireinfluenced air. These values are in broad agreement with the range of observational estimates from the literature. Model $\triangle \mathrm{PAN} / \triangle \mathrm{CO}$ enhancement ratios show distinct groupings according to the meteorological data used to drive the models. ECMWF-forced models produce larger $\triangle \mathrm{PAN} / \triangle \mathrm{CO}$ values (4.47 to $7.00 \mathrm{pptv}^{\mathrm{ppbv}}{ }^{-1}$ ) than GEOS5-forced models (1.87 to $3.28 \mathrm{pptv}_{\mathrm{ppbv}}{ }^{-1}$ ), which we show is likely linked to differences in efficiency of vertical transport during poleward export from mid-latitude source regions. Simulations of a large plume of biomass burning and anthropogenic emissions exported from towards the Arctic using a Lagrangian chemical transport model show that 4-day net ozone change in the
\end{abstract}

plume is sensitive to differences in plume chemical composition and plume vertical position among the POLMIP models. In particular, Arctic ozone evolution in the plume is highly sensitive to initial concentrations of PAN, as well as oxygenated VOCs (acetone, acetaldehyde), due to their role in producing the peroxyacetyl radical PAN precursor. Vertical displacement is also important due to its effects on the stability of PAN, and subsequent effect on $\mathrm{NO}_{x}$ abundance. In plumes where net ozone production is limited, we find that the lifetime of ozone in the plume is sensitive to hydrogen peroxide loading, due to the production of $\mathrm{HO}_{x}$ from peroxide photolysis, and the key role of $\mathrm{HO}_{2}+\mathrm{O}_{3}$ in controlling ozone loss. Overall, our results suggest that emissions from biomass burning lead to large-scale photochemical enhancement in high-latitude tropospheric ozone during summer. 


\section{Introduction}

Vegetation fires play an important role in ecosystem function and regulation (Bonan, 2008) and contribute substantially to atmospheric $\mathrm{CO}_{2}$, with gross emissions from biomass burning estimated to be between 2 and $4 \mathrm{PgCa}^{-1}$ globally, equivalent to $40 \%$ of those from fossil fuel combustion (Ciais et al., 2013). Biomass burning also impacts atmospheric chemistry, releasing large quantities of aerosol and reactive gas-phase chemical compounds, including $\mathrm{CO}, \mathrm{NO}_{x}$ $\left(=\mathrm{NO}+\mathrm{NO}_{2}\right)$ and volatile organic compounds (VOCs) (Andreae et al., 1988; van der Werf et al., 2010). These emissions result in perturbations to tropospheric oxidants, aerosol loading and the atmospheric radiative balance. Studies have demonstrated that wildfires in the boreal regions of North America and Eurasia affect abundances of atmospheric trace gases and aerosol at high latitudes (Bourgeois and Bey, 2011; Fisher et al., 2010; Hornbrook et al., 2011; Jaffe and Wigder, 2012; Monks et al., 2012; Paris et al., 2009; Real et al., 2007; Warneke et al., 2010; Wofsy et al., 1992). These contributions peak during spring and summer, when large fires occur naturally in the regions of Alaska and Canada and in central and eastern Siberia (Monks et al., 2012; van der Werf et al., 2010). How anthropogenic and natural sources of climatically relevant atmospheric constituents will contribute to future high-latitude climate change is highly uncertain (Shindell et al., 2008). In particular, our understanding of how boreal fires impact large-scale Arctic and high-latitude budgets of climate-relevant atmospheric constituents is limited, and is reliant on sparse observations, often in specific events and isolated plumes. Short-lived climate pollutants (SLCPs) such as tropospheric ozone, aerosol and methane may contribute to accelerated rates of warming observed in the Arctic relative to the global mean temperature increase (Quinn et al., 2008). Changes in tropospheric ozone and aerosol may already have contributed $0.2-0.4$ and $0.5-1.4^{\circ} \mathrm{C}$, respectively, to Arctic surface warming since 1890 (Shindell and Faluvegi, 2009). A better understanding of boreal fire influence on high-latitude tropospheric ozone and aerosol is essential for improving the reliability of our projections of future Arctic and Northern Hemisphere climate change, especially considering proposed climate-fire feedbacks which may enhance the intensity and extent of high-latitude wildfire under a warming climate (de Groot et al., 2013).

The role of boreal fires as a source of high-latitude tropospheric ozone is particularly poorly constrained, and has been the subject of some controversy, with different studies suggesting both minor and major roles for fires as a source of Arctic ozone. A recent review by Jaffe and Wigder (2012) showed that most studies have demonstrated net production of tropospheric ozone from wildfire emissions, due to the propensity of fires to emit large quantities of key ozone precursors $\left(\mathrm{NO}_{x}, \mathrm{CO}, \mathrm{VOCs}\right)$. The $\Delta \mathrm{O}_{3} / \Delta \mathrm{CO}$ enhancement ratio (defined as the excess ozone mixing ratio above background ozone in an air mass normalized by an enhance- ment in $\mathrm{CO}$ mixing ratio above background $\mathrm{CO}$ ), is often used as a measure of ozone production efficiency in fire plumes as they are processed downwind from emission. Values of $\Delta \mathrm{O}_{3} / \Delta C O$ in boreal wildfire plumes from Siberia, Alaska and Canada vary between approximately -0.1 and $0.6 \mathrm{ppbv} \mathrm{ppbv}^{-1}$ (Alvarado et al., 2010; Bertschi et al., 2004; Goode et al., 2000; Honrath et al., 2004; Val Martin et al., 2006; Mauzerall et al., 1996; Paris et al., 2009; Parrington et al., 2013; Pfister et al., 2006; Real et al., 2007; Singh et al., 2010; Tanimoto et al., 2008; Wofsy et al., 1992). In addition, these values are observed to generally increase with increasing plume age.

A robust estimate of the role of boreal fires in producing tropospheric ozone is hampered by a large range in observational estimates of ozone production efficiency, likely resulting from factors such as variability in emission factors with combustion efficiency and vegetation type, differences in plume age, different plume chemical processing, due to e.g. different aerosol loadings, and mixing with anthropogenic emissions (Jaffe and Wigder, 2012). Integrated analysis of data from multiple boreal fire plumes sampled across Alaska and Canada during the ARCTAS-B campaign concluded that boreal fire emissions had only negligible impact on tropospheric ozone profiles in summer 2008 over Alaska and Canada (Alvarado et al., 2010; Singh et al., 2010). However, plumes sampled were mostly freshly emitted ( $<2$ days), and box modelling based on the same data suggests high in situ photochemical production rates, despite little to no measured ozone enhancement in these plumes (Olson et al., 2012). Other recent modelling studies have suggested greater ozone sensitivity to boreal fire emissions in more aged air masses. Tropospheric ozone in coastal Canada has been shown to be highly sensitive to $\mathrm{NO}_{x}$ emissions from central Canadian fires (Parrington et al., 2012), and regional modelling for the Arctic in summer 2008 suggests that ozone production increases markedly in fire plumes downwind from emission as air masses process chemically over time (Thomas et al., 2013). Wespes et al. (2012), using a tagged $\mathrm{NO}_{x}$ and ozone production scheme in the MOZART4 global CTM, showed that more than $20 \%$ of ozone in the Arctic lower troposphere is produced from $\mathrm{NO}_{x}$ emitted from high-latitude fires in North America and Asia. Boreal forest fires have also been shown to be an important source of peroxyacetyl nitrate (PAN) in the Arctic during the spring and summer months (Jacob et al., 1992; Singh et al., 2010, 1992). Transport of PAN from lower latitudes into the Arctic makes a substantial contribution to local in situ ozone production, via $\mathrm{NO}_{2}$ released from PAN decomposition (Walker et al., 2012).

In light of uncertainties associated with these contributions, there is a need to better evaluate how models simulate the influence of boreal fires on high-latitude budgets of ozone and precursors, particularly in summer, when local radiative processes play a major role in Arctic surface temperatures (Shindell, 2007). While several model studies have 
Table 1. Description of POLMIP models.

\begin{tabular}{llll}
\hline Model & Resolution & Meteorology & Chemistry \\
\hline CAM4-Chem & $1.9^{\circ} \times 2.5^{\circ}, 56$ levels & GEOS-5 & MOZART-4, bulk aerosols \\
CAM5-Chem & $1.9^{\circ} \times 2.5^{\circ}, 56$ levels & GEOS-5 & MOZART-4, modal aerosols \\
CIFS & $1.125^{\circ} \times 1.125^{\circ}, 60$ levels & ECMWF & tropospheric, CB05 \\
GEOS-Chem & $2^{\circ} \times 2.5^{\circ}, 47$ levels & GEOS-5 & tropospheric, 100 species \\
GMI & $2^{\circ} \times 2.5^{\circ}, 72$ levels & GEOS-5 & $\begin{array}{l}\text { stratospheric and tropospheric, } \\
\end{array}$ \\
LMDZ-INCA & $1.9^{\circ} \times 3.75^{\circ}, 39$ levels & ERA-Interim & tropospheric, 85 species, aerosols \\
MOZART-4 & $1.9^{\circ} \times 2.5^{\circ}, 56$ levels & GEOS-5 & tropospheric, 103 species, bulk aerosols \\
TM5 & $2^{\circ} \times 3^{\circ}, 60$ levels & ECMWF & tropospheric, CB05 \\
TOMCAT & $2.8^{\circ} \times 2.8^{\circ}, 31$ levels & ECMWF & tropospheric, 82 species \\
SMHI-MATCH & $0.75^{\circ} \times 0.75^{\circ}, 35$ levels (hemispheric) & ECMWF & 63 tracers, 110 gas-phase reactions \\
& & & Stratosphere: Monthly means from EU- \\
& & & MACC project (MOZART-4) \\
\hline
\end{tabular}

investigated simulated ozone production from boreal fires, there has been little attempt to understand how differences in model treatments of chemistry and transport affect estimates of ozone production in fire-influenced air masses.

In this paper, we use results from POLMIP (POLARCAT model intercomparison Project) (Emmons et al., 2014) and observations collected in the Arctic troposphere as part of the ARCTAS-B mission (Jacob et al., 2010), to evaluate simulated summertime tropospheric ozone and its precursors in the northern high latitudes and how it is influenced by boreal fire emissions in a series of state-of-the-art global atmospheric chemical transport models. The POLMIP model experiments and observations used to evaluate them are described in Sect. 2. In Sect. 3, we use idealized model tracers to track fire emissions, and compare ozone enhancement ratios $\left(\Delta \mathrm{O}_{3} / \Delta \mathrm{CO}\right)$ in air dominated by fire emission influence across the range of models, and investigate relationships with model $\mathrm{NO}_{y}$ partitioning. Section 4 describes a case study of a large biomass burning plume exported from Siberia in July 2008, which we use to investigate the sensitivities of Arctic tropospheric ozone to model chemistry based on Lagrangian chemical model simulations of the plume. Our findings and conclusions are summarized in Sect. 5.

\section{Model simulations and observations}

The POLARCAT Model Intercomparison Project (POLMIP) was designed to evaluate the performance of several globaland regional-scale chemical transport models (CTMs) in the Arctic troposphere (Emmons et al., 2014). POLMIP contributes to the POLARCAT project aim to better understand model deficiencies identified in a previous evaluation of CTM simulations of Arctic tropospheric ozone and its precursors, and aims to exploit the large amount of observational data collected during the IPY aircraft experiments in the Arctic troposphere during spring and summer 2008. Fur- ther details on the POLARCAT project and the 2008 aircraft campaigns are given in Law et al. (2014). All models used the same data for emissions, with the aim of allowing an investigation of model differences due to atmospheric transport and chemical processes only. The exception was the GEOSChem model, which used different anthropogenic emissions (Emmons et al., 2014). POLMIP anthropogenic emissions are those provided for the ARCTAS project by D. Streets (Argonne National Lab) and University of Iowa (http://bio. cgrer.uiowa.edu/arctas/emission.html). Daily biomass burning emissions are taken from the Fire Inventory of NCAR (FINN), based on MODIS fire counts (Wiedinmyer et al., 2011). All POLMIP models injected biomass burning emissions into the lowest boundary layer model level, in order to remove any differences produced through treatments of fire emission injection heights. Other emissions (biogenic, ocean, volcano) were derived from the MACCity inventory (Lamarque et al., 2010). Table 1 summarizes details of the POLMIP model simulations used in this study. Further details of the POLMIP model experiments, emissions data and evaluation of the simulations can be found in Emmons et al. (2014).

In addition to using different anthropogenic emissions, the GEOS-Chem model includes a parametrization for transition metal-catalyzed formation of $\mathrm{H}_{2} \mathrm{O}$ from aerosol uptake of $\mathrm{HO}_{2}$, rather than formation of $\mathrm{H}_{2} \mathrm{O}_{2}$. This process is effectively an irreversible loss for $\mathrm{HO}_{x}$, and is motivated by the suggestion from field observations that $\mathrm{HO}_{2}$ uptake to aerosol may not produce $\mathrm{H}_{2} \mathrm{O}_{2}$. This motivation and the implementation of this scheme are described by Mao et al. (2013a). The same study showed that inclusion of this process reduces the mass-weighted global mean $\mathrm{OH}$ concentration by $12 \%$, and substantially increases CO concentrations at high latitudes due to an increased CO lifetime. It was also shown to reduce surface ozone by 3-10 ppbv over North America and Eurasia.

To further aid in understanding inter-model differences in transport, POLMIP models included fixed-lifetime tracers 
from anthropogenic and biomass burning emission sources. A total of six tracers were simulated, each with a prescribed fixed atmospheric lifetime of 25 days. A 25-day tracer lifetime is sufficiently long relative to the transport timescale for long-range transport from mid-latitudes to the Arctic (days to a week), while being short enough to avoid the formation of a homogeneous well-mixed tracer distribution. Two tracers were emitted from each of three mid-latitude continental source regions (Europe, North America and Asia), one with the same source as the anthropogenic $\mathrm{CO}$ emissions and one from the $\mathrm{CO}$ emissions from biomass burning sources. Details on the exact definition of source regions and emission magnitudes are given in Emmons et al. (2014). The Asian biomass burning tracer is dominated by emissions from large Siberian fires in July 2008 (see Emmons et al., 2014). Monks et al. (2012) demonstrated that variability in emissions from boreal fires dominates the inter-annual variability of the ozone precursor, $\mathrm{CO}$ in the Arctic troposphere. Using the fixed-lifetime CO tracers from the POLMIP simulations, in conjunction with observed and simulated $\mathrm{CO}$, Monks et al. (2015) investigated the contributions from differences in model transport and oxidants to inter-model variability in simulated seasonal CO in the Arctic. They showed that emissions from Asian fires are the dominant source of $\mathrm{CO}$ tracer in the lower and middle summertime Arctic troposphere, and are approximately equal to the contribution from Asian anthropogenic sources in the upper troposphere. Here, we exploit these tracers to identify regions and periods in the POLMIP model simulations for which air is strongly influenced by fire emissions.

Several aircraft flew missions into the Arctic troposphere during summer 2008 as part of the POLARCAT experiment (Law et al., 2014). The POLARCAT-France and GRACE experiments, based in Southwest Greenland, sampled aged fire plumes and anthropogenic air masses transported into the Arctic from Siberia and North America. ARCTAS-B, based in central Canada, sampled fresh and aged fire emissions over Canada and the Arctic. In this analysis, we make use only of data from the ARCTAS-B mission, for which the NASA DC8 aircraft was equipped with an extensive suite of gas phase and aerosol instrumentation, including ozone, $\mathrm{CO}$, speciated oxides of nitrogen $\left(\mathrm{NO}_{y}\right)$, volatile organic compounds and peroxides (Jacob et al., 2010). Monks et al. (2015) present a detailed comparison of the POLMIP model simulations with $\mathrm{CO}$ and ozone data from all POLARCAT experiments.

During ARCTAS-B, the DC8 aircraft made seven flights, based from Cold Lake, Canada from 29 June to 10 July 2008. The vast majority of observations were made in fresh Saskatchewan fire plumes, although some flights also targeted aged plumes transported to Canada from Siberian and Californian fires. All ARCTAS DC8 data are available in a publicly accessible archive (http://www-air.larc.nasa.gov/ cgi-bin/arcstat-c), and described in Jacob et al. (2010).

\section{Fire emission influence on ozone and $\mathrm{NO}_{y}$ enhancement in POLMIP models}

\subsection{Evaluation of model ozone and ozone precursors in air dominated by fire emissions}

Using the fixed-lifetime tracers from the models, we evaluate simulations of ozone and precursors against ARCTAS$B$ aircraft observations in air dominated by fire emissions in the summertime Arctic troposphere. Figures 1-4 respectively show aircraft observations of ozone, CO, PAN and $\mathrm{HNO}_{3}$ plotted against hourly model output interpolated in time and space to the aircraft position. For each model, points have been coloured according to whether the simulated tracers from fire sources or from anthropogenic sources contribute more than $50 \%$ of the total (fire + anthropogenic) tracer mixing ratio at the aircraft location. In model air dominated by fire emissions, simulated ozone generally falls close to the observation-model $1: 1$ line, and model median biases vary between -22 and $+5 \%$, compared with -19 to $-2 \%$ in anthropogenic-dominated air. As discussed in detail by Monks et al. (2015), all POLMIP models display a negative $\mathrm{CO}$ bias, throughout the depth of the troposphere. Use of the POLMIP fixed-lifetime tracers shows that this is the case in both anthropogenic and fire-dominated air. Global models typically underestimate $\mathrm{CO}$ in the northern extratropics. A recent multi-model study showed negative annual mean model biases exceeding $-45 \mathrm{ppbv}$ compared with surface $\mathrm{CO}$ observations at high latitudes, and as large as $-30 \mathrm{ppbv}$ compared with satellite-retrieved $\mathrm{CO}$ concentrations at $500 \mathrm{hPa}$ over the extra-tropical oceans (Naik et al., 2013). The majority of ARCTAS-B observations were made in fresh biomass burning plumes, leading to larger $\mathrm{CO}$ concentrations on average in fire-dominated air masses. The models also simulate larger $\mathrm{CO}$ concentrations in these air masses, but with a general underestimate. Monks et al. (2015) demonstrated that POLMIP model-simulated global mean $\mathrm{OH}$ was generally biased slightly high compared with observational constraints, possibly contributing to their low CO bias.

Simulated distributions of $\mathrm{NO}_{y}$ species show some of the largest diversity between models and largest fractional biases against observations. Emmons et al. (2014) showed that POLMIP models display large variability in their budgets of $\mathrm{NO}_{y}$ throughout the depth of the Arctic troposphere. The POLMIP models fall into two distinct groups in terms of their simulation of ARCTAS-B PAN concentrations. Models forced by GEOS5 meteorology tend to have lower PAN than observed in fire-dominated air (median biases: -47 to $-28 \%$ ), while the ECMWF-forced models produce PAN concentrations close to or larger than those observed in firedominated air (median biases: -2 to $+24 \%$ ). This major difference appears to be related to differences in the efficiency of vertical transport between models using the two different sets of meteorological data (see Sect. 3.3). Models that 

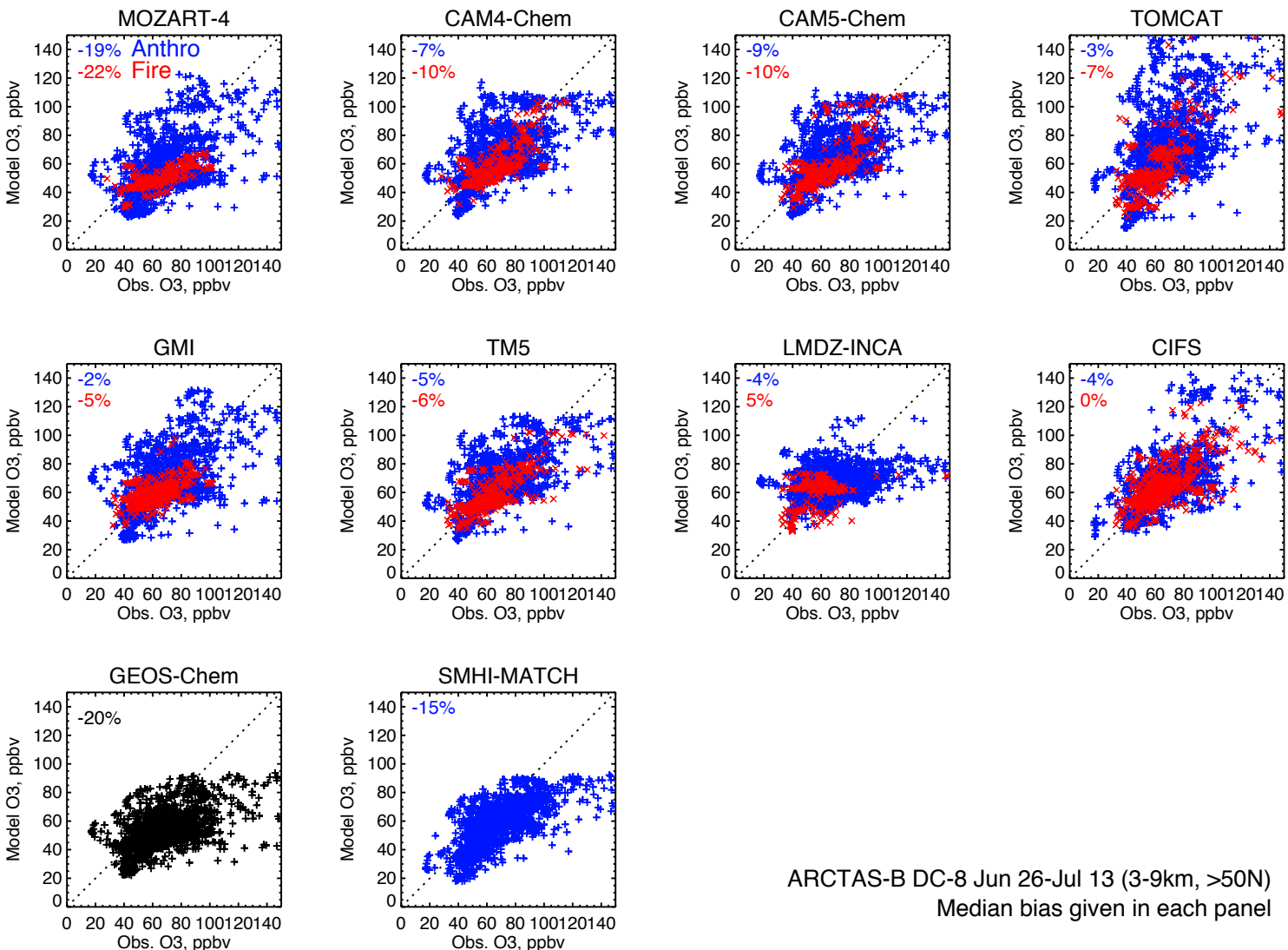

ARCTAS-B DC-8 Jun 26-Jul $13(3-9 \mathrm{~km},>50 \mathrm{~N})$
Median bias given in each panel

Figure 1. POLMIP model ozone interpolated to selected ARCTAS-B DC8 flight tracks north of $50^{\circ} \mathrm{N}$, and between 3-9 km altitude plotted as a function of the DC8-observed concentrations. Blue and red colours show model points which are dominated by anthropogenic and biomass burning emissions respectively, as diagnosed by 25-day fixed-lifetime $\mathrm{CO}$ tracers simulated by the models (see text for details). Mean fractional model biases (\%) in anthropogenic- and fire-dominated air are shown in blue and red text respectively. The GEOS-Chem model did not simulate 25-day fixed-lifetime tracers.

transport PAN and its precursors more rapidly to higher altitudes and lower temperatures will likely promote enhanced PAN formation and stability (Singh and Hanst, 1981). These effects on differences in $\mathrm{NO}_{y}$ partitioning are explored further in Sect. 3.3.

GEOS-Chem underestimates DC8 PAN concentrations by the largest magnitude overall (median bias $-51 \%$ ), with lower-than-observed PAN at all locations where observed PAN exceeds 250 pptv. Recent work has substantially improved the simulation of PAN in the GEOS-Chem model (Fischer et al., 2014), however these model updates are not included here. The CIFS model shows very large PAN overestimates ( $>$ factor of 4 ) in fire air masses sampled close to the surface. Comparisons with aircraft observations (see Emmons et al., 2014) show coincident overestimates in $\mathrm{NO}_{2}$ and acetaldehyde, suggesting that these very large PAN concentrations may be partly produced by overestimates in PAN precursors near to fire source regions. In general, the models display substantially larger range in PAN biases in fire-dominated air (median biases: -47 to $+24 \%$ ) compared with anthropogenic-dominated air (median biases:
-34 to $+5 \%$ ). Fresh biomass burning plumes observed in ARCTAS-B displayed enhancements in peroxyacetyl precursors such as acetaldehyde and acetone (Hornbrook et al., 2011). Simulated oxygenated (o)VOC enhancements relative to $\mathrm{CO}$ (particularly for acetone) in the POLMIP models show large variability close to Canadian fires (Emmons et al., 2014), which may in turn lead to a large range in simulated PAN production. With the exception of the GEOS-Chem and TM5 models, emissions of acetone and acetaldehyde are the same for all models. The large diversity in model concentrations of these species therefore mainly results from different treatments of organic chemistry, differences in rates of photochemical processing of their parent VOCs and differences in their photolysis and $\mathrm{OH}$ loss.

Several models show a large positive bias in Arctic $\mathrm{HNO}_{3}$ concentrations (up to a factor 32 in anthropogenically dominated air). In an earlier study, Alvarado et al. (2010) used the GEOS-Chem model to study $\mathrm{HNO}_{3}$ in fire-influenced air masses. This study concluded that the over-prediction of $\mathrm{HNO}_{3}$ was due to under-prediction of $\mathrm{NO}_{x}$ conversion to PAN in fire-influenced air masses. The POLMIP models 

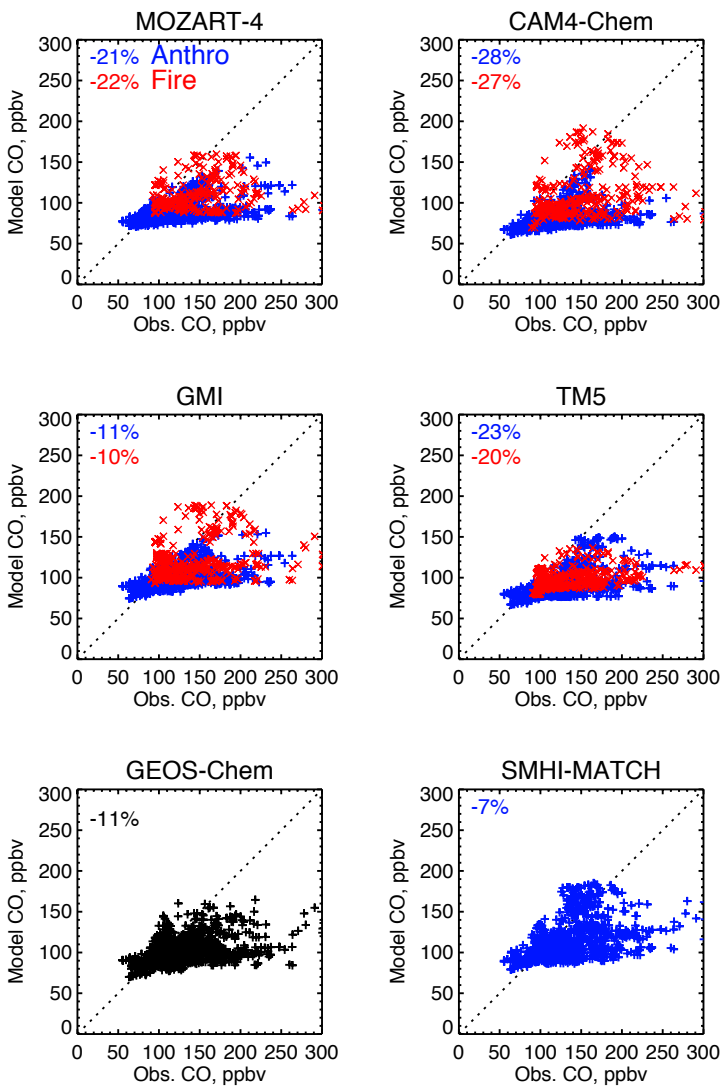

Figure 2. As Fig. 1, but for CO.

do not generally support this offsetting of positive biases in $\mathrm{HNO}_{3}$ with under-prediction of PAN.

\subsection{Model ozone production in fire-dominated Arctic air masses}

Previous studies have directly determined the contribution from fire emissions to model ozone by removing emissions from fires (Pfister et al., 2006; Thomas et al., 2013) or by chemically tagging ozone produced by $\mathrm{NO}_{x}$ emitted from fires (Wespes et al., 2012). To investigate this contribution in the POLMIP models, we use the 25-day fixed-lifetime tracers to identify the dominant emission source that influences high-latitude air in the models. We calculate enhancement in tropospheric ozone as a ratio to $\mathrm{CO}$ enhancement $\left(\Delta \mathrm{O}_{3} / \Delta \mathrm{CO}\right)$ where the fixed-lifetime tracers indicate that the model domain is dominated by fire emissions. Points are considered to be fire-dominated where the fire-sourced fixed-lifetime tracer concentration is at least $66 \%$ of the total fixed-lifetime tracer concentration, and where the firesourced fixed-lifetime tracer mixing ratio is at least $10 \mathrm{ppbv}$. Using this minimum tracer mixing ratio to define air enhanced in fire emissions, we use the slope of $\mathrm{CO}$ vs. ozone in these air masses to calculate the $\Delta \mathrm{O}_{3} / \Delta \mathrm{CO}$ ratio directly. This avoids the definition of a $\mathrm{CO}$ mixing ratio enhancement
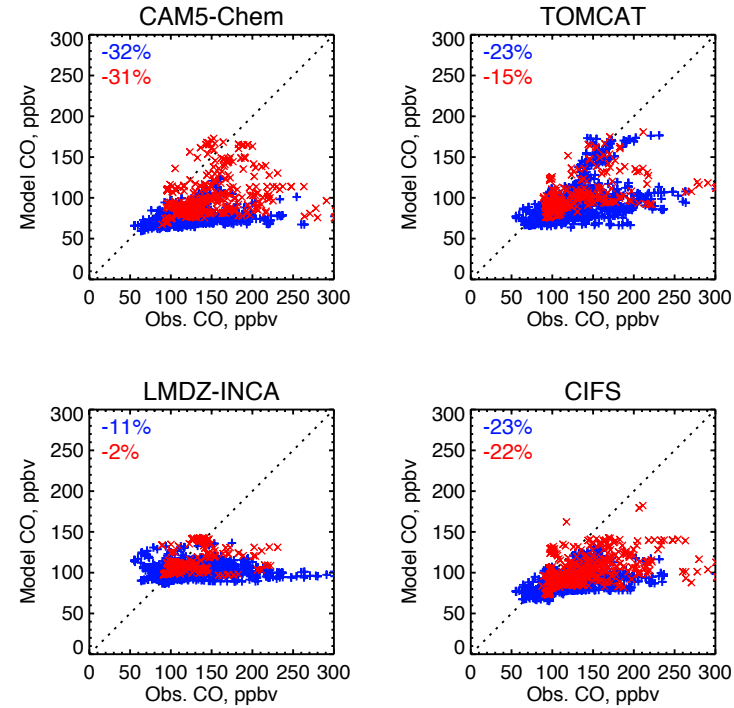

ARCTAS-B DC-8 Jun 26-Jul 13 (3-9km, >50N) Median bias given in each panel

above background $\mathrm{CO}$, which due to $\mathrm{OH}$ differences between the models is highly model dependent (Monks et al., 2015).

Recent studies have highlighted the need for caution regarding the use of $\mathrm{O}_{3} / \mathrm{CO}$ slopes to diagnose photochemical ozone production, particularly in remote regions, due to slopes being artificially increased by chemical loss of $\mathrm{CO}$ due to reaction with $\mathrm{OH}$ (e.g. Voulgarakis et al., 2011; Zhang et al., 2014). Chemical rate output from the MOZART-4 model shows that in the domain of our study (latitude $50-90^{\circ} \mathrm{N}$, $850-250 \mathrm{hPa}$ ) the daily chemical loss rate of CO is small (average $1.9 \mathrm{ppbv} \mathrm{day}^{-1}$ ), equivalent to $1.5-4.5 \%$. This loss is partly offset by chemical production of CO from VOC oxidation (average $0.9 \mathrm{ppbv}^{-1 a y^{-1}}$ ), and daily fractional rates of chemical ozone production at the same locations are substantially larger $(\sim 5-45 \%)$. This analysis suggests that chemical $\mathrm{CO}$ loss is unlikely to have a significant effect on our calculated $\mathrm{O}_{3} / \mathrm{CO}$ slopes.

Using changes in the ratio of concentrations of two coemitted VOCs with differing atmospheric lifetimes, it is also possible to estimate how model $\Delta \mathrm{O}_{3} / \Delta \mathrm{CO}$ values change, as air dominated by fire emissions is transported away from the source region and ages photochemically. For primaryemitted VOCs that have losses dominated by $\mathrm{OH}$-oxidation, the concentration ratio of a more reactive to a less reactive VOC is expected to reduce over time since emission 

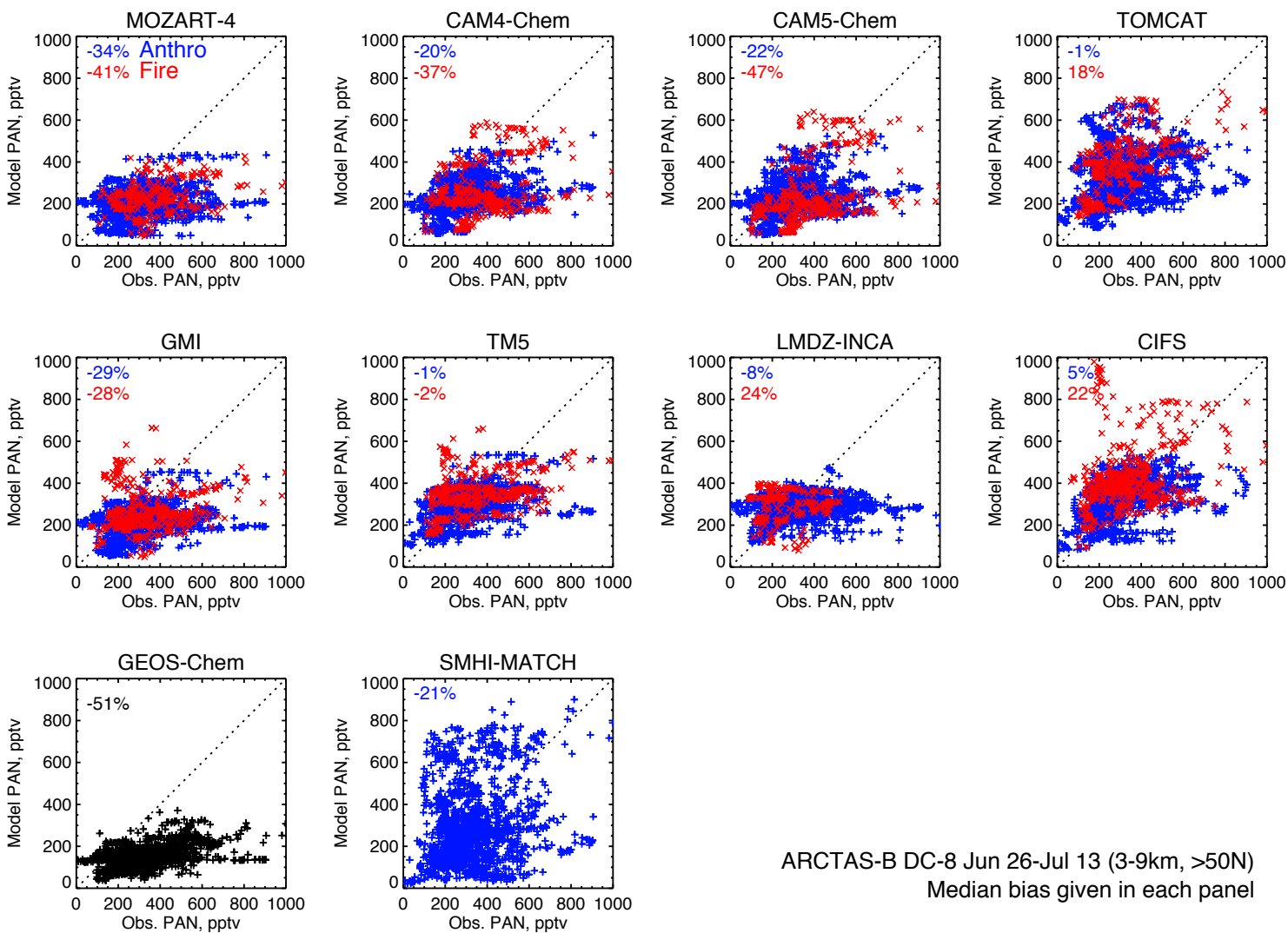

ARCTAS-B DC-8 Jun 26-Jul 13 (3-9km, >50N)

Figure 3. As Fig. 1, but for PAN.

(Calvert, 1976). Propane $\left(\mathrm{C}_{3} \mathrm{H}_{8}\right)$ and ethane $\left(\mathrm{C}_{2} \mathrm{H}_{6}\right)$ have respective atmospheric e-folding lifetimes of approximately 5 and 24 days (for an average $\mathrm{OH}$ concentration of $2 \times$

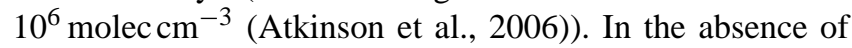
mixing with background concentrations, a decrease in the $\ln \left(\left[\mathrm{C}_{3} \mathrm{H}_{8}\right] /\left[\mathrm{C}_{2} \mathrm{H}_{6}\right]\right)$ ratio is directly proportional to the time elapsed since emission.

We use the $\ln \left(\left[\mathrm{C}_{3} \mathrm{H}_{8}\right] /\left[\mathrm{C}_{2} \mathrm{H}_{6}\right]\right)$ ratios from the POLMIP models to create relationships between broad classifications of air mass age and $\Delta \mathrm{O}_{3} / \Delta \mathrm{CO}$. Based on model values of the $\ln \left(\left[\mathrm{C}_{3} \mathrm{H}_{8}\right] /\left[\mathrm{C}_{2} \mathrm{H}_{6}\right]\right)$ ratio, we separate the distribution of high-latitude tropospheric model grid boxes into two populations of "youngest" (points with $\ln \left(\left[\mathrm{C}_{3} \mathrm{H}_{8}\right] /\left[\mathrm{C}_{2} \mathrm{H}_{6}\right]\right)$ values larger than the mean) and "oldest" (points with $\ln \left(\left[\mathrm{C}_{3} \mathrm{H}_{8}\right] /\left[\mathrm{C}_{2} \mathrm{H}_{6}\right]\right)$ values smaller than the mean) air masses, in terms of their estimated age since emission. Figure 5 shows POLMIP model-simulated relationships between $\left[\mathrm{O}_{3}\right]$ and $[\mathrm{CO}]$ in fire-dominated air in the high-latitude free troposphere (latitude $>50^{\circ} \mathrm{N}$; $850 \mathrm{hPa}>$ pressure $>250 \mathrm{hPa}$ ), with calculated $\Delta \mathrm{O}_{3} / \Delta \mathrm{CO}$ slopes in youngest and oldest air mass groups as defined by the $\ln \left(\left[\mathrm{C}_{3} \mathrm{H}_{8}\right] /\left[\mathrm{C}_{2} \mathrm{H}_{6}\right]\right)$ ratios. The SMHI-MATCH and GEOS-Chem models respectively did not explicitly simulate propane and the fixed-lifetime source tracers. Therefore, it is not possible to calculate $\Delta \mathrm{O}_{3} / \Delta \mathrm{CO}$ slopes in fire-dominated air according to these age classes.

POLMIP model $\Delta \mathrm{O}_{3} / \Delta \mathrm{CO}$ slopes are positive in both the younger and aged fire-dominated air in all models. Slopes in the aged air masses (mean: 0.193, min: 0.140, max: $0.261 \mathrm{ppbv} \mathrm{ppbv}^{-1}$ ) are larger on average compared with slopes in the younger air masses (mean: 0.113 , min: 0.039, max: $0.196 \mathrm{ppbvpbv}^{-1}$ ). This is indicative of photochemical ozone production in fire emission-dominated air emitted into and advected to high latitudes in the POLMIP models, with an increase in ozone enhancement relative to $\mathrm{CO}$ enhancement in these air masses as they age photochemically. Two models (TOMCAT and CAM5-Chem) show a slight decrease in $\Delta \mathrm{O}_{3} / \Delta \mathrm{CO}$ with air mass age defined by the $\ln \left(\left[\mathrm{C}_{3} \mathrm{H}_{8}\right] /\left[\mathrm{C}_{2} \mathrm{H}_{6}\right]\right)$ ratio. Supplementary Fig. S1 shows that the $\ln ([$ propane]/[ethane]) ratio for these models show less distinct separation in their corresponding fire tracer concentrations between the young and old age classes. This suggests that the $\ln \left(\left[\mathrm{C}_{3} \mathrm{H}_{8}\right] /\left[\mathrm{C}_{2} \mathrm{H}_{6}\right]\right)$ ratio may be a less robust proxy for photochemical age since emission in these models. Figure 5k shows ozone and $\mathrm{CO}$ observations from ARCTASB DC8 flights over-plotted with $\Delta \mathrm{O}_{3} / \Delta \mathrm{CO}$ slopes from the different POLMIP models. Although the DC8 aircraft sampled only a small proportion of the fire-dominated domain simulated by the models, the aircraft points lie close to the 

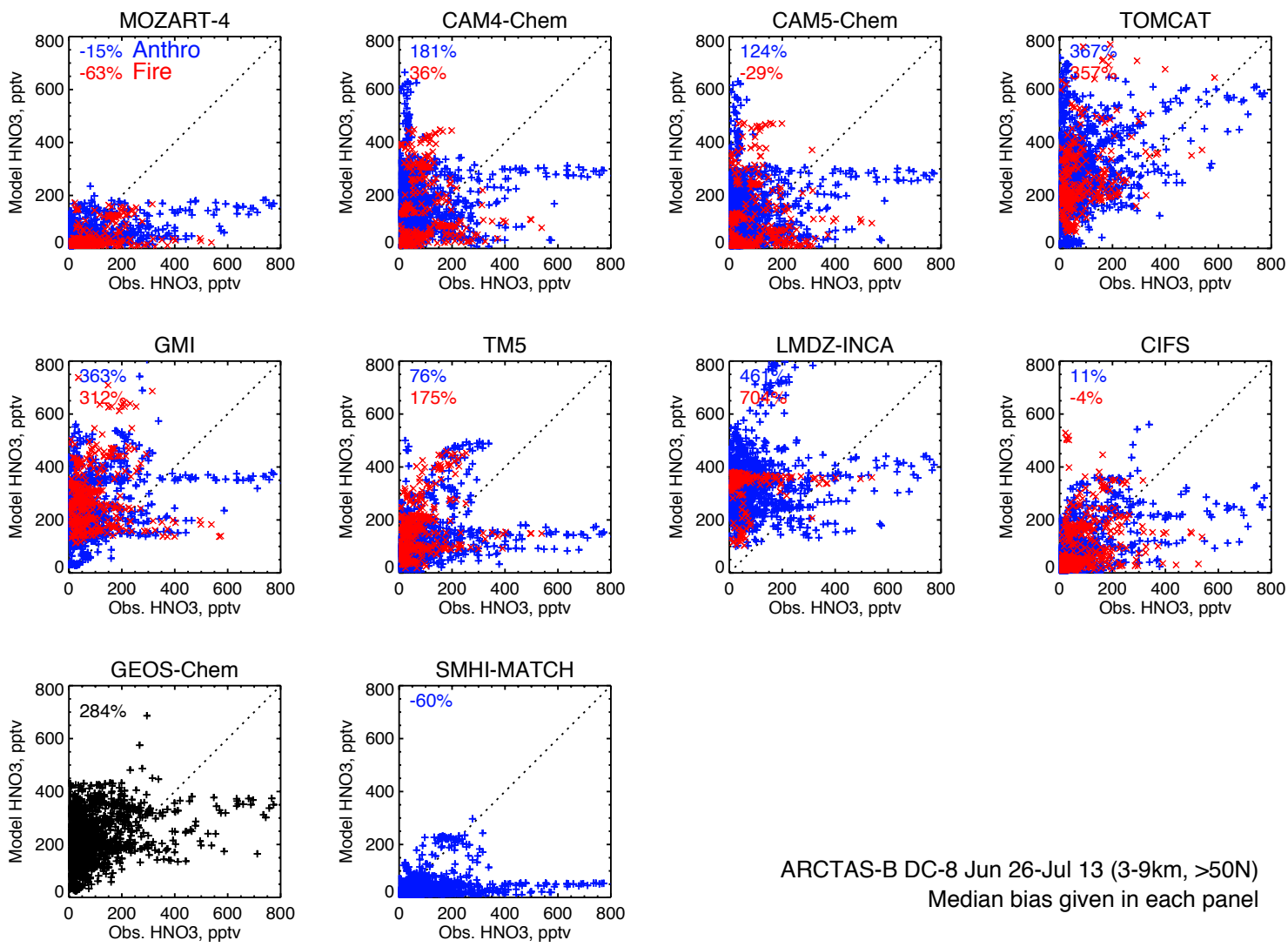

ARCTAS-B DC-8 Jun 26-Jul 13 (3-9km, >50N) Median bias given in each panel

Figure 4. As Fig. 1, but for $\mathrm{HNO}_{3}$.

model $\Delta \mathrm{O}_{3} / \Delta \mathrm{CO}$ slopes. Observed ozone concentrations appear slightly larger as a function of $\mathrm{CO}$ than those in the POLMIP simulations. There is also evidence that observed air masses show a larger range in ozone enhancements for a given range of $\mathrm{CO}$ enhancement than those simulated, perhaps reflecting a diverse range of fresh plumes sampled by the aircraft close to the fires on the model sub-grid scale.

POLMIP model $\Delta \mathrm{O}_{3} / \Delta \mathrm{CO}$ values are highly consistent compared with the wide range of $\Delta \mathrm{O}_{3} / \Delta \mathrm{CO}$ values determined from observational studies in boreal fire plumes. Figure 6 compares the $\Delta \mathrm{O}_{3} / \Delta \mathrm{CO}$ values from the POLMIP models with $\Delta \mathrm{O}_{3} / \Delta \mathrm{CO}$ values from previous model and observational studies on fire plumes at high latitudes. Average $\Delta \mathrm{O}_{3} / \Delta \mathrm{CO}$ values from a previous GEOS-Chem model study based on ARCTAS-B range between -0.07 and 0.01 (Alvarado et al., 2010), substantially smaller than values from the POLMIP models. However, these values were diagnosed in freshly fire-influenced air masses. The POLMIP models agree well with regional WRF-Chem model simulations for the ARCTAS-B campaign, which produced mean $\Delta \mathrm{O}_{3} / \Delta C \mathrm{C}$ values in fresh and aged biomass burning plumes of 0.08 and $0.49 \mathrm{ppbv} \mathrm{ppbv}^{-1}$ respectively, and used the same FINN fire emissions as the POLMIP models (Thomas et al., 2013). Differences in simulated photolysis between the POLMIP models are likely contributors to model spread in photochemical ozone enhancement relative to $\mathrm{CO}$. Such differences are presented and explored for the POLMIP models by Emmons et al. (2014). Mao et al. (2013b), using the GFDL AM3 model with aerosol loss uptake of $\mathrm{HO}_{2}$, characterized a suppressed large-scale ozone enhancement from fires $\left(\Delta \mathrm{O}_{3} / \Delta \mathrm{CO}=0.16\right)$ at high latitudes $\left(>60^{\circ} \mathrm{N}\right) \mathrm{com}$ pared with the tropics. This is also seen in comparisons of observational studies between different latitudes - however, observed $\Delta \mathrm{O}_{3} / \Delta \mathrm{CO}$ at high latitudes is often larger than this large-scale average value derived from their model (Jaffe and Wigder, 2012). Both heterogeneous $\mathrm{HO}_{2}$ loss on aerosol (Mao et al., 2013a, b) and bromine chemistry (Parrella et al., 2012), implemented in GEOS-Chem for POLMIP, may also play a role in reducing tropospheric ozone abundance.

Overlaying $\mathrm{O}_{3} / \mathrm{CO}$ slopes from the other POLMIP models onto plots of GEOS-Chem and SMHI-MATCH $\left[\mathrm{O}_{3}\right]$ vs. [CO] allows some comparison of their Arctic tropospheric $\mathrm{O}_{3}$ enhancement with other POLMIP models. POLMIP model $\mathrm{O}_{3} / \mathrm{CO}$ slopes lie through the $\left[\mathrm{O}_{3}\right]$ vs. [CO] distribution from the SMHI-MATCH model, which at larger [CO], shows a slope value consistent with the smaller slope values from other POLMIP models. GEOS-Chem shows the lowest ozone enhancement as a function of $\mathrm{CO}$ among the POLMIP models, outside of the range of the majority of other models and the ARCTAS-B observations. 
(a) MOZART-4 [G]

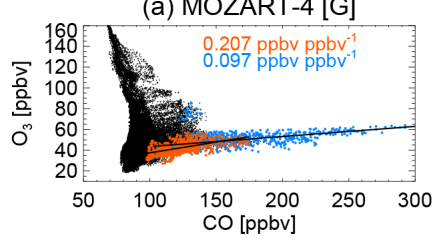

(d) GMI [G]

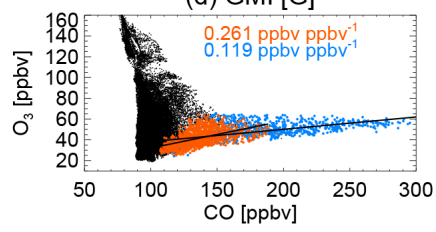

(g) CIFS [E]

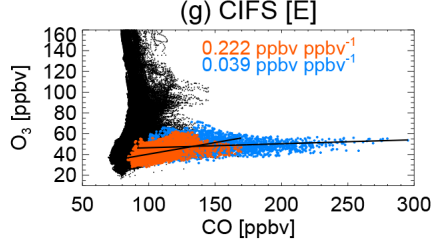

(j) GEOS-Chem [G]

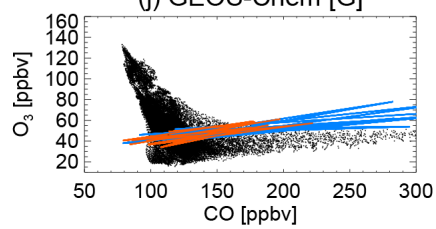

(b) CAM4-Chem [G]

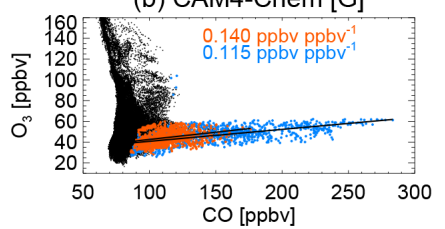

(e) TOMCAT [E]

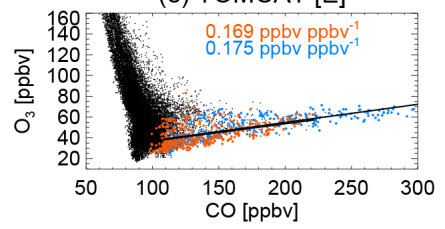

(h) LMDZ-INCA [E]

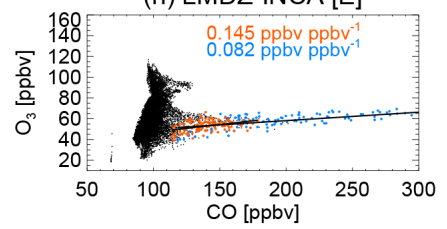

(k) ARCTAS-B observations

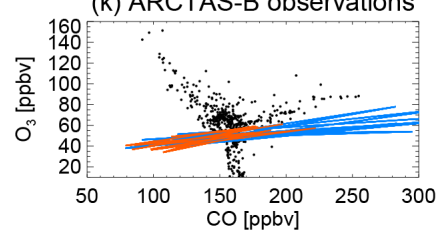

(c) CAM5-Chem [G]

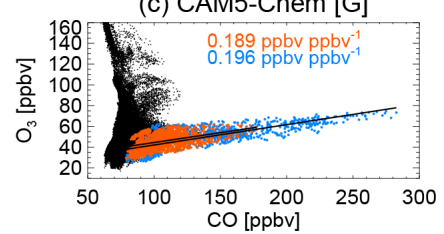

(f) TM5 [E]
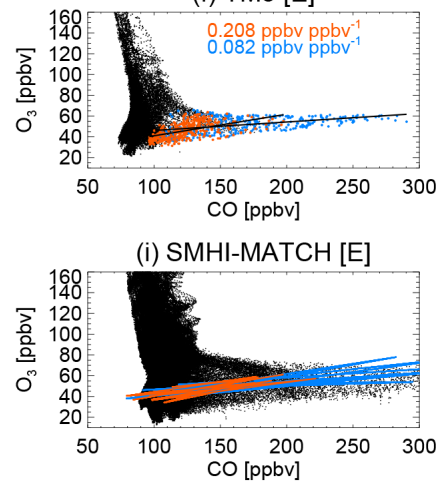

Figure 5. July 2008 monthly mean $\mathrm{O}_{3}$ vs. CO from POLMIP model simulations coloured by fire influence and relative age of air since emission. Black: all points north of $50^{\circ} \mathrm{N}$, with $850 \mathrm{hPa}>$ pressure $>250 \mathrm{hPa}$. Coloured points show model grid boxes where the fireemitted fixed-lifetime $\mathrm{CO}$ tracer contributes more than $66 \%$ of the total (fire + anthropogenic) tracer mixing ratio. Blue and red points denote younger than average and more aged than average of these points respectively, as diagnosed by the $\ln \left(\left[\mathrm{C}_{3} \mathrm{H}_{8}\right] /\left[\mathrm{C}_{2} \mathrm{H}_{6}\right]\right) \operatorname{concentration}$ ratio. Models that did not simulate fixed-lifetime tracers, or do not carry $\left[\mathrm{C}_{3} \mathrm{H}_{8}\right]$ explicitly, do not have coloured points, but instead show slopes from linear regressions of the coloured points from the other models (red and blue lines). Blue and red text give $\Delta \mathrm{O}_{3} / \Delta \mathrm{CO}$ slope values from linear regressions of the youngest and most aged populations respectively. Letters in square brackets denote the meteorological analysis data used to drive the models - E: ECMWF; G: GEOS-5. Panel (k) shows ARCTAS-B aircraft observations.

\subsection{High-latitude PAN enhancement in POLMIP models}

Enhancements in PAN relative to $\mathrm{CO}$ in the high-latitude troposphere in the POLMIP models show grouping according to the source of meteorological data used to drive the models. Analogous to the ozone enhancement ratio $\left(\Delta \mathrm{O}_{3} / \Delta C O\right)$, $\Delta \mathrm{PAN} / \triangle \mathrm{CO}$ can be used to evaluate the efficiency of PAN formation and its transport to high latitudes in the POLMIP models (Fig. 7). Observations show that PAN was the dominant $\mathrm{NO}_{y}$ component in the Arctic troposphere during summer 2008 (Alvarado et al., 2010; Liang et al., 2011), and as a source of $\mathrm{NO}_{x}$, may be an important driver of tropospheric ozone production at high latitudes (Walker et al., 2012). Average $\triangle \mathrm{PAN} / \Delta \mathrm{CO}$ values in GEOS5-forced models range between $1.87-3.28$ pptv ppbv $^{-1}$, and in ECMWFforced models range between $4.47-7.00 \mathrm{pptv}_{\mathrm{ppbv}}{ }^{-1}$. Along with the biases shown in Fig. 3, this further suggests that major differences in summertime $\mathrm{NO}_{y}$ partitioning may be driven by differences in model vertical transport efficiency.
While differences in PAN abundances in the Arctic troposphere shown in Fig. 3 could be explained by differences in efficiency of poleward pollution transport in the models generally, differences in $\triangle \mathrm{PAN} / \triangle \mathrm{CO}$ slopes reflect inter-model variability in the efficiency of PAN production or transport relative to $\mathrm{CO}$. $\mathrm{CO}$ has a long atmospheric lifetime relative to the transport timescales characteristic of poleward frontal export, and is dominated by primary emissions. Therefore, $\triangle \mathrm{PAN} / \triangle \mathrm{CO}$ variability likely represents differences in the rate of PAN formation and its stability. This may be driven by different efficiencies of air mass uplift during boundary layer export, promoting PAN stability, or differences in organic chemistry, controlling the abundance of the acetyl peroxy radical precursor.

The vertical distributions of the 25-day fixed-lifetime CO tracers in the models indicate a more vertically well-mixed lower troposphere in the ECMWF models compared with the GEOS- 5 models in general. Figure 8 shows zonal mean differences in tracers between 900 and $500 \mathrm{hPa}$ at Northern Hemisphere mid-latitudes in spring and summer. In 


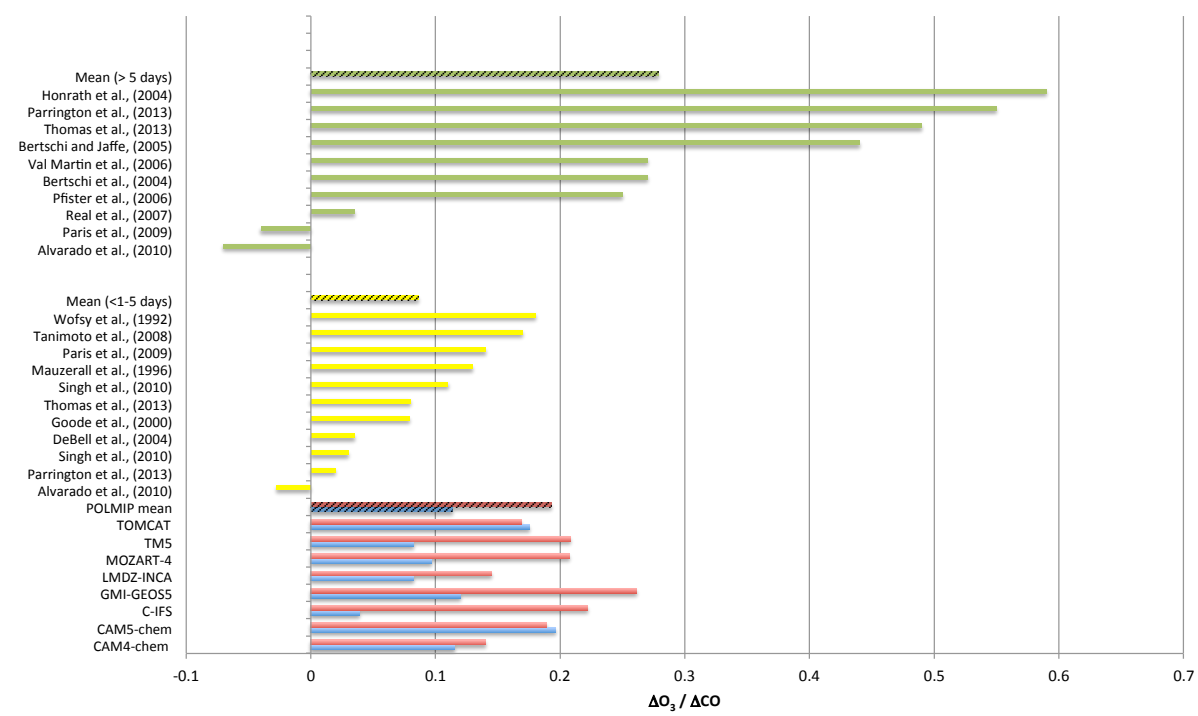

Figure 6. $\Delta \mathrm{O}_{3} / \Delta \mathrm{CO}$ ratios in boreal biomass burning pollution from previous studies and from the POLMIP model simulations analysed in this study. Green: values from plumes of age $>5$ days; yellow: values from plumes of age $<1-5$ days. POLMIP model values are classified by age since emission (red: aged; blue: young), based on the $\ln \left(\left[\mathrm{C}_{3} \mathrm{H}_{8}\right] /\left[\mathrm{C}_{2} \mathrm{H}_{6}\right]\right.$ ) concentration ratio (see text for details). Hatched bars indicate average values for each category. Literature values for previous studies are based on an updated version of the review of Jaffe and Wigder (2012).

spring, TOMCAT, TM5 and CIFS show a weaker vertical tracer gradient than CAM4-Chem, CAM5-Chem, MOZART4 and GMI, suggesting less efficient vertical transport in the GEOS5-driven models over mid-latitude source regions. This pattern is less clear in summer, however between 45 and $55^{\circ} \mathrm{N}$ this general behaviour is evident among the same models, with the exception of MOZART-4, which becomes more vertically well mixed. Mid-latitude convection is likely more important for vertical transport in summer. Increased convective vertical mixing in the models may therefore mask some of the differences in vertical tracer structure produced by differences in large-scale vertical transport.

Average values of $\triangle \mathrm{PAN} / \triangle \mathrm{CO}$ from a range of fresh and aged fire plumes sampled during ARCTAS-B varied between 2.8 and 0.35 pptv ppbv $^{-1}$ (Alvarado et al., 2010), in better agreement with values produced by the GEOS5-driven models. Figure 7k shows PAN and CO from ARCTAS-B observations. Observed PAN/CO slopes are broadly consistent with those simulated by the POLMIP models. The majority of observations support larger slopes consistent with the ECMWFdriven models. The largest PAN enhancements are produced by the CIFS model, which also shows the largest overall positive bias $(+40 \%)$ against high-latitude PAN observations (Fig. 3). Across all POLMIP models, we see no robust relationship between increased Arctic PAN import efficiency and increased ozone production efficiency $\left(\Delta \mathrm{O}_{3} / \Delta C O\right)$. Differences in photochemistry between the models likely determine the efficiency with which $\mathrm{NO}_{y}$ import is manifested in high-latitude ozone enhancement. In addition, a reduction in $\mathrm{NO}_{x}$ through more rapid PAN formation in the ECMWF models, and consequent suppression of ozone production in plumes transported poleward may also play a role (Jacob et al., 1992; Mauzerall et al., 1996).

The $\mathrm{NO}_{y}$ biases shown by GEOS-Chem are consistent with those shown in Alvarado et al. (2010), who found that PAN and $\mathrm{HNO}_{3}$ in the GEOS-Chem model were under- and overestimated respectively by almost a factor of 2 . In particular, the large negative bias in high-latitude PAN (Fig. 3) may explain the lower ozone enhancement compared with other POLMIP models. This bias is largest among the POLMIP models. The simulated low PAN abundances are unlikely explained by the composition of emissions, since all POLMIP models use the same fire emissions.

\section{Arctic fire plume sensitivities to model chemistry}

In order to further investigate the sensitivities of high-latitude tropospheric ozone production to differences in POLMIP model $\mathrm{NO}_{y}$ partitioning and photochemistry in fire plumes, we analyse chemical processing during the export of a large plume of Siberian biomass burning and anthropogenic emissions from Asia to the Arctic. By carrying out additional simulations using a Lagrangian chemical transport model, we quantify how differences in chemical composition of this plume between the POLMIP models following export from Asia and poleward transport, and differences in subsequent transport in the Arctic, impact the evolution of ozone in the plume. 
(a) MOZART-4 [G]

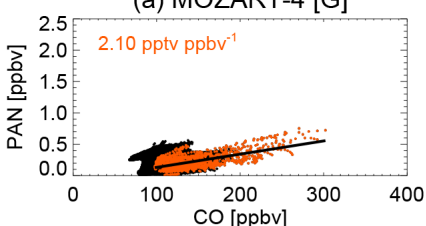

(d) GMI [G]

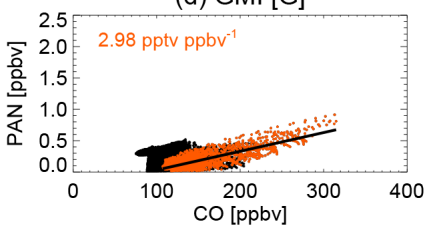

(g) CIFS [E]

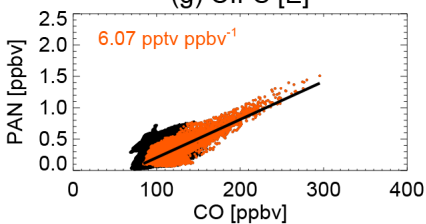

(j) GEOS-Chem [G]

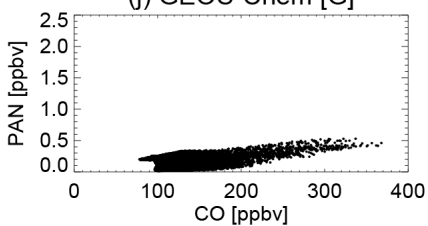

(b) CAM4-Chem [G]

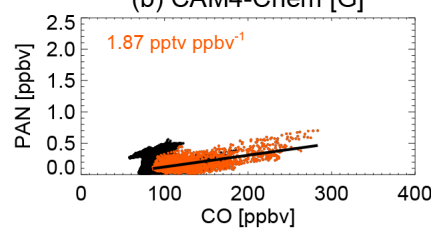

(e) TOMCAT [E]

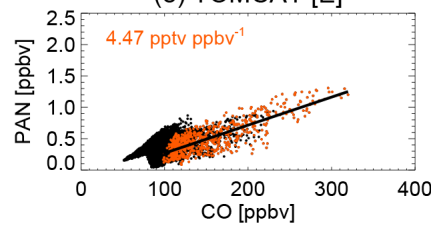

(h) LMDZ-INCA [E]

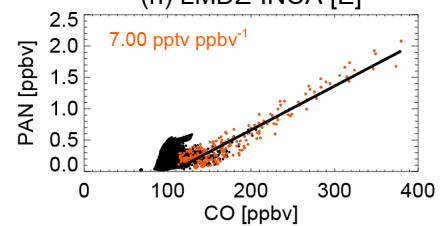

(k) ARCTAS-B observations

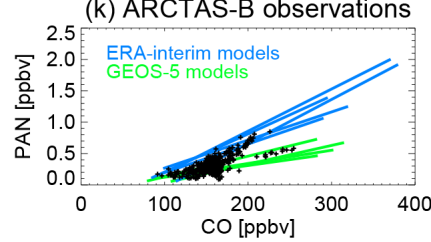

(c) CAM5-Chem [G]

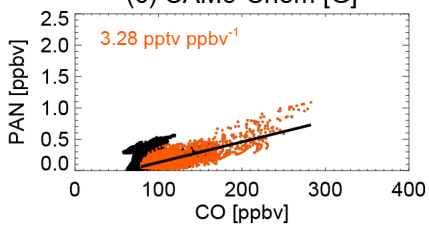

(f) TM5 [E]

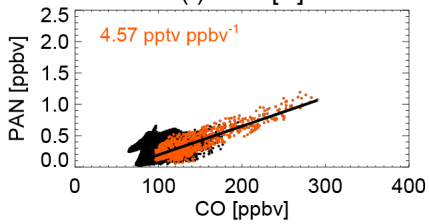

(i) SMHI-MATCH [E]

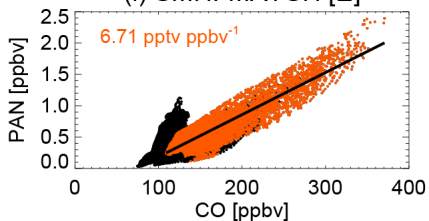

Figure 7. July 2008 PAN/CO relationships for POLMIP models coloured by fire influence. Black: all points north of $50^{\circ} \mathrm{N}$, with $850 \mathrm{hPa}>$ pressure $>250 \mathrm{hPa}$. Red points show model grid boxes where the fire fixed-lifetime CO tracer contributes more than $66 \%$ of the total (fire + anthropogenic) tracer mixing ratio. Red text gives $\triangle \mathrm{PAN} / \Delta C \mathrm{C}$ slope values for linear regressions of the red points. GEOSChem model did not supply fixed-lifetime tracers. Letters in square brackets denote the meteorological analysis data used to drive the models - E: ECMWF; G: GEOS-5. Panel (k) shows ARCTAS-B aircraft observations with slopes from ECMWF (blue) and GEOS-5 (green) models shown for comparison.
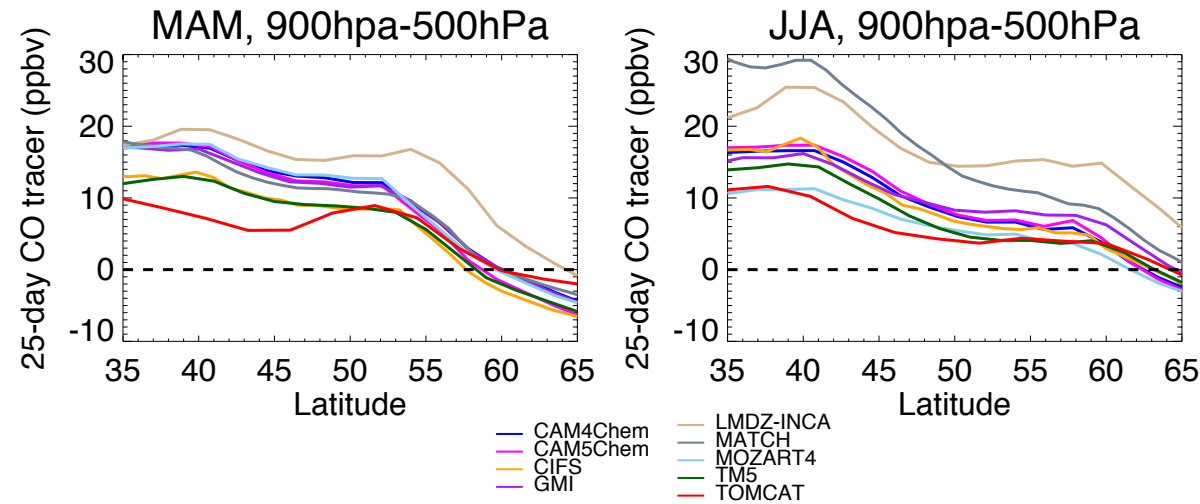

Figure 8. Zonally averaged difference between simulated 25-day fixed-lifetime CO tracer mixing ratios at 900 and $500 \mathrm{hPa}$ in the POLMIP model simulations for (a) spring (MAM) and (b) summer (JJA) 2008.

\subsection{Siberian biomass burning and Asian anthropogenic plume case study}

Between 6 and 9 July 2008, a low-pressure system travelled from Siberia across the Arctic Ocean towards the North
Pole, carrying with it smoke plumes from Siberian wildfires and emissions from anthropogenic sources in East Asia. This extensive plume of polluted air was sampled both remotely from satellite and by aircraft in situ measurements. The IASI (Infrared Atmospheric Sounding Interferometer) 
satellite instrument observed the plume as a large feature of enhanced $\mathrm{CO}$ that was exported from the Asian east coast and advanced towards the North Pole (Pommier et al., 2010). On 6 and 7 July the plume was between 850 and $1600 \mathrm{~km}$ wide, large enough to be represented on the grid-scale of the POLMIP global models. As part of ARCTAS-B, the DC8 aircraft also sampled the plume on 9 July, between 80 and $85^{\circ} \mathrm{N}$, to the north of Greenland. Despite excessive diffusion in the polar region due to the singularity at the pole on the Eulerian global grid, Sodemann et al. (2011) showed that the TOMCAT global model was able to capture the largescale export of the plume, its horizontal position, and its poleward transport into the Arctic region. This event provides a good case study for evaluation of differences in transport and chemistry of fire-influenced pollution to the Arctic among the POLMIP models.

The general horizontal position, size and shape of the plume agree well between the different POLMIP model simulations. This is likely due to the use of the same emissions data in each model, and large-scale horizontal flow associated with the low-pressure system being largely consistent between different driving meteorological data. Figure 9 shows total column CO from the POLMIP models at 06:00 UT on 7 July 2008, just as the leading edge of the plume reaches $80^{\circ} \mathrm{N}$, at $\sim 180^{\circ} \mathrm{W}$. The plume extent and position simulated by the POLMIP models is also consistent with the observed IASI satellite CO columns (Sodemann et al., 2011). The positions and relative enhancement of simulated column CO maxima are controlled by simulated horizontal transport and diffusive processes at the sub-plume scale, but also vertical transport processes which control the export $\mathrm{CO}$ from the boundary layer and the extent to which exported pollution layers remain distinct or become vertically diffusive.

There are large differences in the magnitude of $\mathrm{CO}$ simulated in the plume. Differences in model $\mathrm{OH}$ have been shown to have a strong influence on inter-model variability in Arctic CO in the POLMIP models (Monks et al., 2015). These same differences are evident in Fig. 9, particularly in $\mathrm{CO}$ column differences in Arctic background air surrounding the plume enhancements. Figures 10 and 11 show column distributions of 25-day lifetime tracers emitted from Asian anthropogenic and Asian fire sources respectively. The lower-resolution models tend to simulate more diffuse and poleward penetration of anthropogenic-emitted tracer into the Arctic compared with the CIFS model.

Although the plume appears as a largely coherent single feature in total column $\mathrm{CO}$, the fixed-lifetime tracers reveal large-scale separation of anthropogenic and fire contributions. The leading edge of the plume in all models is dominated by fire emissions, with the main part of the anthropogenically sourced air mass further to the south (Fig. 10). Backward modelling simulations with the FLEXPART Lagrangian particle dispersion model have also demonstrated that when this plume was sampled by the DC8 aircraft on
9 July 2008, CO contributions from anthropogenic and fire sources showed large-scale separation, with Asian fossil fuel sourced CO dominating above $6-7 \mathrm{~km}$ altitude (Sodemann et al., 2011). Enhanced CO from the anthropogenic part of this plume was transported into the lowermost stratosphere, and was sampled by the DLR Falcon aircraft during the POLARCAT-GRACE campaign on 10 July 2008 (Roiger et al., 2011). The separation between anthropogenic and fire influence within the plume is highly consistent across the POLMIP models, suggesting good agreement in the locations of export and large-scale horizontal transport of emissions from these two sources from the Asian boundary layer to the Arctic. The GMI and MOZART-4 model plume maxima are situated at lower altitudes compared to the other models (Table 2), again consistent with less efficient vertical export in GEOS5-driven models (Fig. 8).

\subsection{Lagrangian chemical model simulations}

From each of the POLMIP global model simulations, the position of the plume maximum is determined from the plume distributions shown in Fig. 9. Maxima locations are determined by locating the model grid box that contains the maximum Asian fire tracer mixing ratio in the horizontal and vertical in the region of the simulated plume. Table 2 shows the longitude, latitude and pressure of plume maxima in the POLMIP models at 06:00 UT on 7 July 2008, following export from the Asian continental boundary layer and import into the Arctic. Table 2 also shows POLMIP model concentrations of key species for ozone photochemistry at these maxima locations. From these maxima locations in each POLMIP model, Lagrangian forward air mass trajectories are calculated using the ROTRAJ (Reading Offline Trajectory) Lagrangian transport model (Methven et al., 2003). Kinematic forward-trajectories from the plume maxima locations are calculated by integration of velocity fields taken from operational analyses of the European Centre for Mediumrange Weather Forecasts (ECMWF). The fields at the Lagrangian particle positions are obtained from the $1.0125^{\circ}$ horizontal resolution analyses by cubic Lagrange interpolation in the vertical followed by bilinear interpolation in the horizontal and linear interpolation in time. Five-day forwardtrajectories were calculated with position output every $6 \mathrm{~h}$. These trajectories account for large-scale advection by the resolved model winds, and neglect convective and turbulent transport.

Using initial chemical conditions from Table 2, and following the forward trajectories calculated from the plume maxima locations for each POLMIP model, we carry out Lagrangian chemical box model simulations using the CiTTyCAT (Cambridge Tropospheric Trajectory model of Chemistry and Transport) Lagrangian CTM (Pugh et al., 2012). The aim of these simulations is to test the sensitivity of ozone in the plume to differences in the chemical composition and the vertical position of the plume following import into the 
(o) MOZART -4

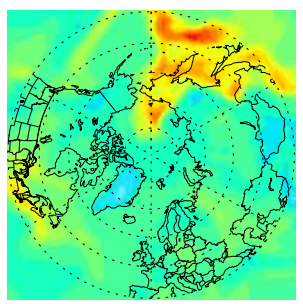

(e) TOMCAT

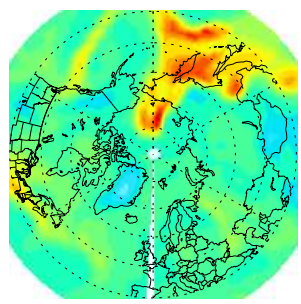

(i) SMHI-MATCH

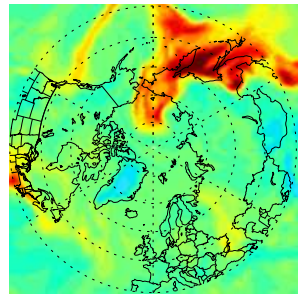

(b) CAM4-Chem

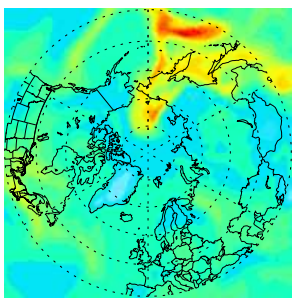

(f) TM5

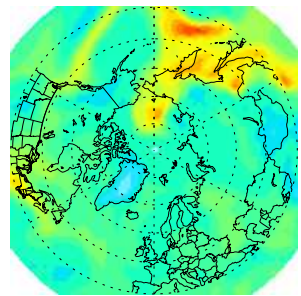

(j) GEOS-Chem

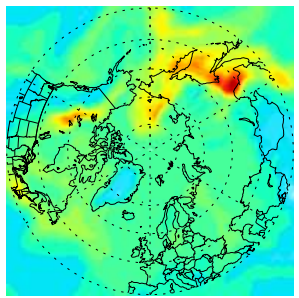

(c) CAM5-Chem

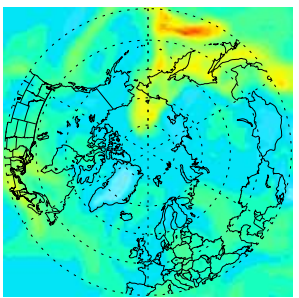

(g) CIFS

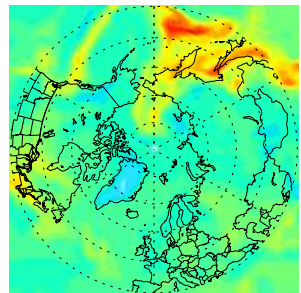

(d) $\mathrm{GMI}$

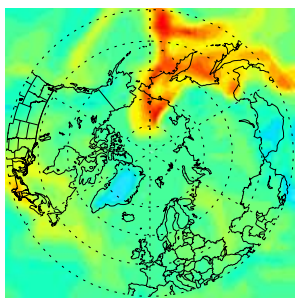

(h) LMDZ-INCA

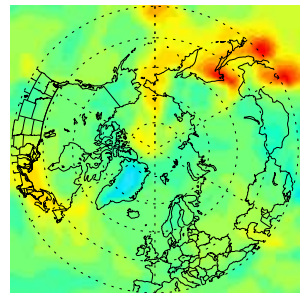

Figure 9. Total column CO from the POLMIP model simulations at 06:00 UT on 7 July 2008.

(a) MOZART-4

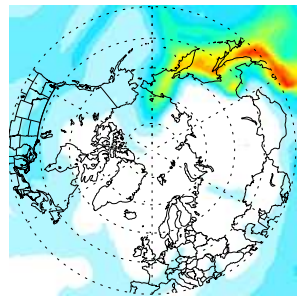

(e) TOMCAT

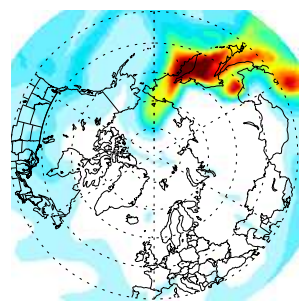

(b) CAM4-Chem

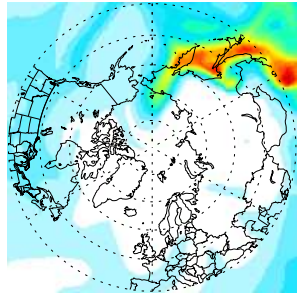

(f) TM5

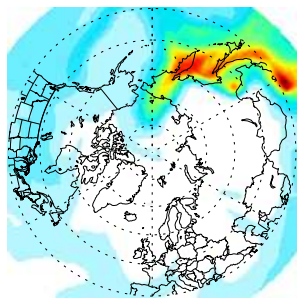

(c) CAM5-Chem

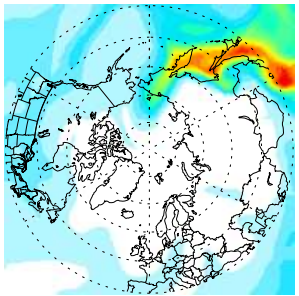

(g) CIFS

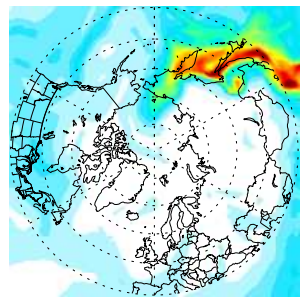

(d) GMI

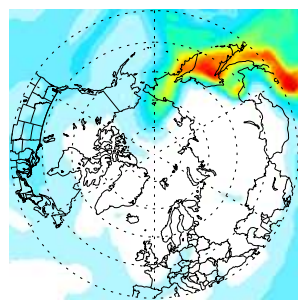

(h) LMDZ-INCA

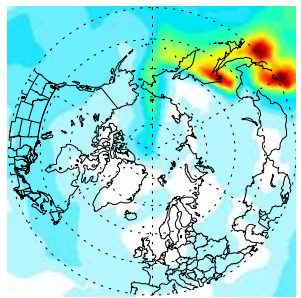

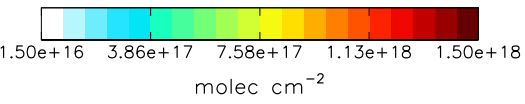

Figure 10. Total column concentrations of the 25 day fixed-lifetime Asian anthropogenic tracer from the POLMIP model simulations at 06:00 UT on 7 July 2008. 
(a) MOZART-4

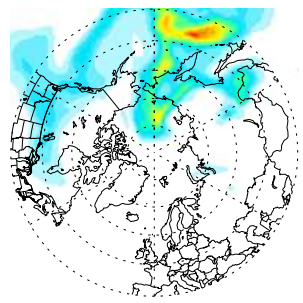

(e) ТОМСАТ

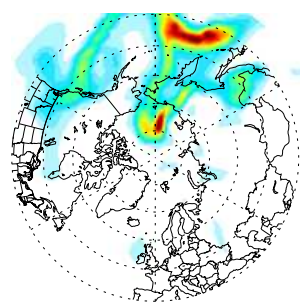

(b) CAM4-Chem

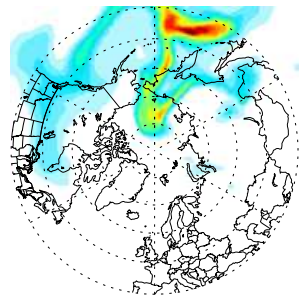

(f) TM5

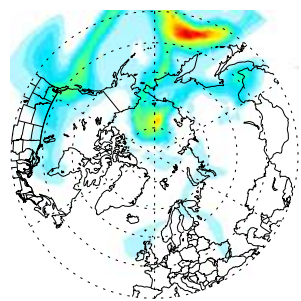

(c) CAM5-Chem

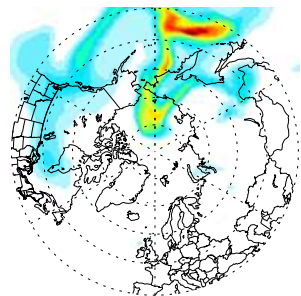

(g) CIFS

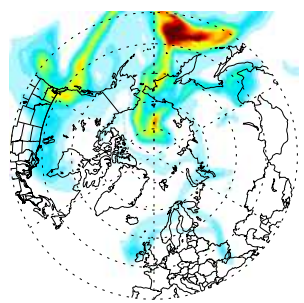

(d) GMI

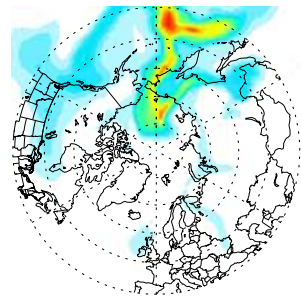

(h) LMDZ-INCA

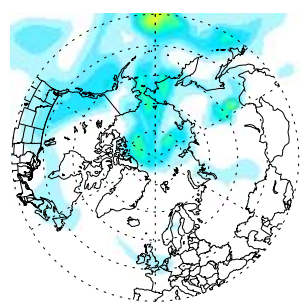

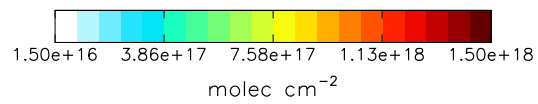

Figure 11. Total column concentrations of the 25-day fixed-lifetime Asian fire tracer from the POLMIP model simulations at 06:00 UT on 7 July 2008.

Table 2. Positions and chemical composition of fire plume maxima in the POLMIP model simulations at 06:00 UT on 7 July 2008. Plume maxima positions are defined based on abundance of simulated 25 day fixed-lifetime Asian biomass burning tracer. See text for details.

\begin{tabular}{|c|c|c|c|c|c|c|c|}
\hline & CAM4-Chem & CAM5-Chem & GMI & LMDZ-INCA & MOZART-4 & TM5 & TOMCAT \\
\hline Longitude & 202.5 & 200.0 & 182.5 & 228.8 & 172.5 & 169.5 & 205.3 \\
\hline Latitude & 78.6 & 78.6 & 72.0 & 80.5 & 76.7 & 83.0 & 76.7 \\
\hline Pressure $[\mathrm{hPa}]$ & 433.8 & 433.5 & 737.1 & 442.7 & 709.6 & 422.1 & 418.1 \\
\hline Ozone [ppbv] & 57.8 & 61.7 & 62.0 & 64.8 & 43.7 & 53.6 & 75.6 \\
\hline $\mathrm{CO}[\mathrm{ppbv}]$ & 292.0 & 280.3 & 332.3 & 218.8 & 251.0 & 215.8 & 364.1 \\
\hline NO [pptv] & 0.850 & 1.336 & 8.731 & 5.743 & 0.300 & 4.974 & 6.281 \\
\hline $\mathrm{NO}_{2}[\mathrm{pptv}]$ & 0.663 & 1.079 & 32.473 & 7.612 & 5.721 & 2.618 & 7.815 \\
\hline $\mathrm{HONO}_{2}[\mathrm{pptv}]$ & 4.912 & 0.757 & 784.2 & 288.3 & 0.093 & 2.580 & 463.9 \\
\hline PAN [pptv] & 182.7 & 207.3 & 93.86 & 407.1 & 97.41 & 448.6 & 1476. \\
\hline $\mathrm{H}_{2} \mathrm{O}_{2}$ [ppbv] & 1.115 & 1.719 & 3.492 & 0.000 & 1.235 & 0.000 & 2.120 \\
\hline $\mathrm{MeOOH}[\mathrm{ppbv}]$ & 0.425 & 0.579 & 1.034 & 0.000 & 0.836 & 0.476 & 0.000 \\
\hline $\mathrm{C}_{2} \mathrm{H}_{6}$ [ppbv] & 2.165 & 2.067 & 2.451 & 1.642 & 1.779 & 1.653 & 2.637 \\
\hline $\mathrm{C}_{3} \mathrm{H}_{8}[\mathrm{ppbv}]$ & 0.128 & 0.083 & 0.130 & 0.078 & 0.101 & 0.082 & 0.110 \\
\hline Acetone $[\mathrm{ppbv}]$ & 1.456 & 1.417 & 0.000 & 0.746 & 1.185 & 0.345 & 1.445 \\
\hline Acetaldehyde [ppbv] & 0.051 & 0.046 & 0.069 & 0.022 & 0.126 & 0.015 & 0.054 \\
\hline $\mathrm{OH}\left[10^{6}\right.$ molec $\left.^{-3}\right]$ & 0.42 & 0.65 & 1.07 & 0.45 & 0.05 & 0.46 & 0.48 \\
\hline
\end{tabular}

Arctic. Using the same Lagrangian model, Real et al. (2007) simulated photochemistry in an Alaskan biomass burning plume advected over the North Atlantic Ocean and sampled sequentially by several research aircraft. The model was able to reproduce the observed ozone change in the plume observed between aircraft interceptions. We use the CiTTyCAT model in single box mode, with a chemical time step of $5 \mathrm{~min}$ and physical conditions taken from the ECMWF trajectory data (position, temperature, specific humidity) updated ev- ery $30 \mathrm{~min}$. Photochemical kinetic data are updated with information where available from the JPL recommendation (Sander et al., 2011), with further data from IUPAC (Atkinson et al., 2004, 2006; Crowley et al., 2010) and the Leeds Master Chemical Mechanism (http://mcm.leeds.ac.uk). In the absence of adequate observations of aerosol size distribution in the plume, we specify fixed aerosol surface area based on observed aerosol size distributions in the boreal fire plume analysed by Real et al. (2007). This surface area 

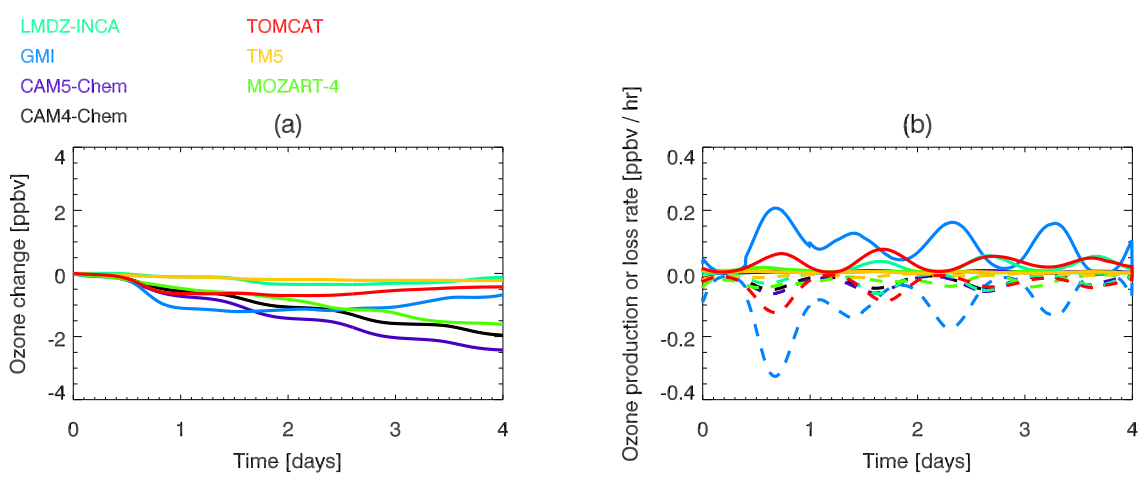

(c)

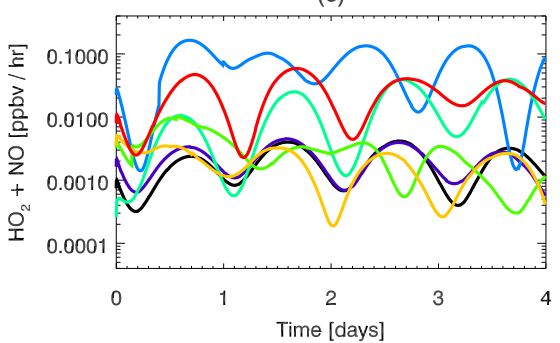

(d)

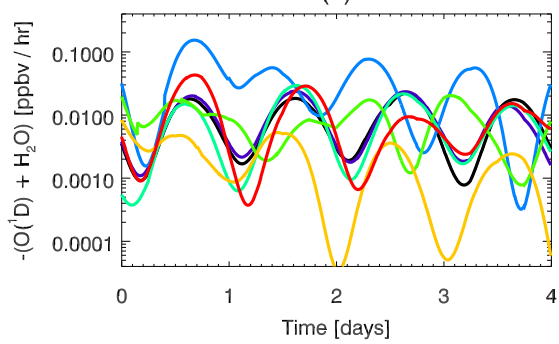

(e)

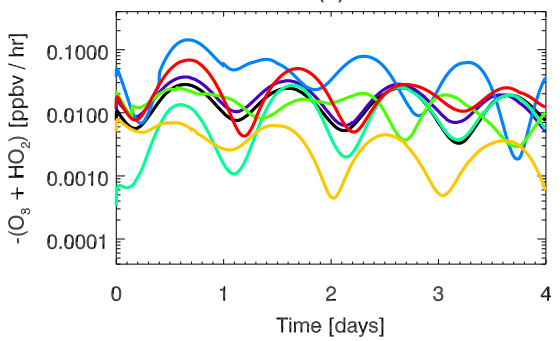

(f)

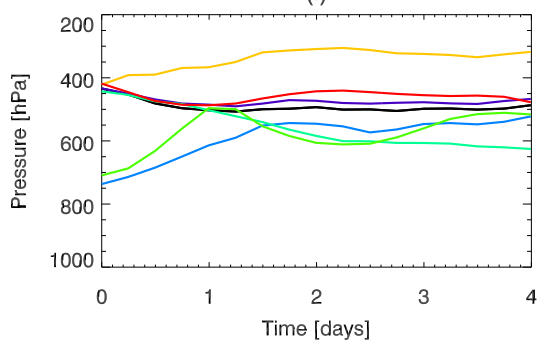

Figure 12. CiTTyCAT Lagrangian box model simulations of fire plume ozone evolution in the Arctic. Coloured lines show simulations initialized with chemical composition from each of the POLMIP global models at the fire plume maxima locations at 06:00 UT on 7 July 2008. (a) Net ozone change over the 4-day simulations. (b) Integrated ozone production (solid) and loss (dashed) rates. (c) $\mathrm{Rate}$ of $\mathrm{HO}_{2}+\mathrm{NO}$ ozone production; (d) Rate of $\mathrm{O}\left({ }^{1} \mathrm{D}\right)+\mathrm{H}_{2} \mathrm{O}$ ozone loss; (e) Rate of $\mathrm{HO}_{2}+\mathrm{O}_{3}$ ozone loss; (f) Pressure of forward trajectories from each POLMIP model plume maximum position used for the Lagrangian simulations. See text for details of the Lagrangian model simulations.

$\left(3.0 \times 10^{-6} \mathrm{~cm}^{2} \mathrm{~cm}^{-3}\right)$ is used to calculate rates of heterogeneous chemistry in the CiTTyCAT plume simulations. In order to isolate sensitivities to chemical composition of the plume, we use a single chemistry scheme in the CiTTyCAT Lagrangian simulations (Pugh et al., 2012), and a single set of meteorological data (ECMWF operational analyses data) to calculate transport of the plume forward from 06:00 UT on 7 July 2008.

\subsection{Simulated plume ozone change and sensitivities to transport and chemistry}

We investigate the range of plume ozone production and loss rates produced by the diversity in chemical initial conditions and forward transport from the plume maxima positions in the POLMIP models. Figure 12a shows simulated 4-day ozone change from the CiTTyCAT model in the plume when initialized by different POLMIP model chemical conditions and when following individual forward trajectories from plume maxima locations. The 4-day evolution of pressure along each of these trajectories is shown in Fig. 12f. The 4-day ozone change differs by $\sim 2.5 \mathrm{ppbv}$ across the range of POLMIP model initial concentrations and forward trajectories, with some models showing near-zero net ozone change (TM5, LMDZ-INCA), while others show net ozone loss of more than 2 ppbv (CAM4-Chem, CAM5-Chem). These differences are produced both by differences in the chemical composition of the plume and different transport pathways forwards over the 4-day period. In particular, differences in plume altitude and subsequent vertical displacement over the 4 days affects the formation and stability of PAN, as well as the balance between ozone production and loss via the reactions of $\mathrm{O}\left({ }^{1} \mathrm{D}\right)$ with water vapour and of $\mathrm{O}_{3}+\mathrm{HO}_{2}$ (Fig. 12d, e). 


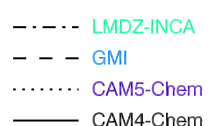

-

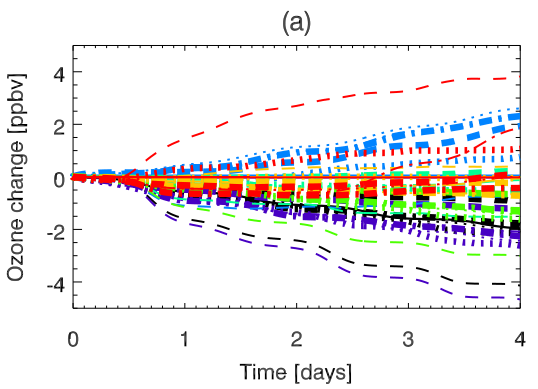

$=$
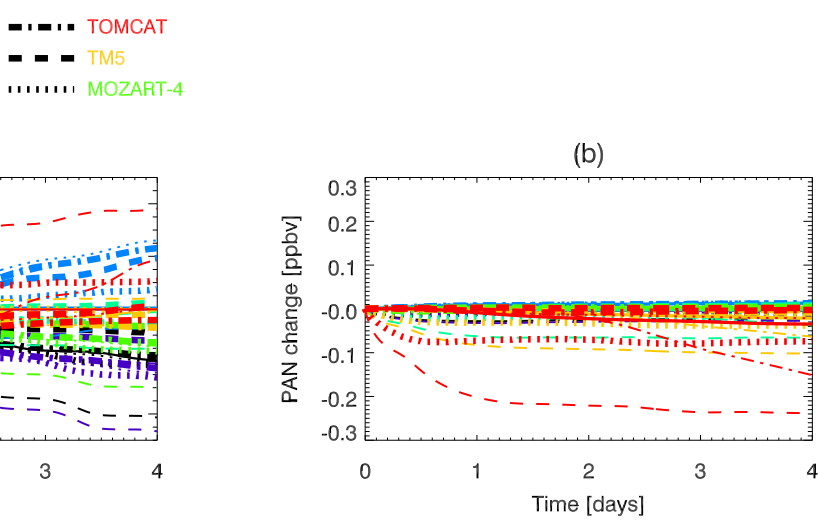

Figure 13. Time evolution of fire plume ozone (a) and PAN (b) from CiTTyCAT Lagrangian model simulations in which the initial plume concentrations from each of the POLMIP models have been used in combination with each of the forward trajectories from the different POLMIP model plume positions (shown in Fig. 12f). Different colours correspond to the POLMIP model initial chemical conditions and line styles correspond to POLMIP model forward trajectories.

All plume simulations result in net ozone loss over 4 days, with ozone destruction dominated by the reaction of $\mathrm{O}_{3}+$ $\mathrm{HO}_{2}$. The TM5-initialized plume shows very little net ozone change, likely due to its relatively high altitude, suppressing both ozone production due to PAN stability and ozone loss due to the dry upper tropospheric conditions of the Arctic. The GMI-initialized plume shows a large ozone production tendency of 2 ppbvday ${ }^{-1}$ on average, which is balanced by large ozone loss rates of slightly larger but similar magnitude (Fig. 12b). Larger ozone production tendency is driven by the larger $\mathrm{NO}_{x}$ concentrations in this plume compared to those initialized from the other POLMIP models. Similar strong $\mathrm{NO}_{x}$ limitation of ozone production in Arctic biomass burning plumes was first noted during flights made in western Alaska during the ABLE3A mission (Jacob et al., 1992). The cycle of ozone production and loss rates in this simulation also suggests that the pathway followed by this plume from its initial position favours more efficient photochemistry, due to exposure to relatively more hours of peak solar radiation.

The simulated ozone change shows strong sensitivity to the physical position and displacement of the air mass forward trajectories. Figure 13 shows net changes in ozone and PAN from analogous CiTTyCAT simulations in which forward trajectories from each of the seven model plume locations have been used in conjunction with the seven sets of chemical initial conditions from the POLMIP models. This produces an ensemble of 49 Lagrangian model simulations, with varying combinations of chemical composition and physical displacement. This diversity produces a much larger range in ozone change over 4 days (approx. -5 to +4 ppbv). Several simulations initialized by chemical conditions from the TOMCAT and GMI models result in net ozone production (Fig. 13a). These models have plume compositions enhanced in $\mathrm{NO}_{x}$ and PAN compared with the other POLMIP models (Table 2). In particular, the conversion of enhanced PAN from the TOMCAT initial state to
$\mathrm{NO}_{x}$ (Fig. 13b) results in enhanced ozone production in forward trajectories that descend (LMDZ-INCA, MOZART-4) or begin at lower altitudes (GMI) (Fig. 12f).

Additional plume simulations using the CiTTyCAT model and the model-specific forward trajectories, reveal strong sensitivity of ozone in the plume to chemical composition simulated by the POLMIP models. We have investigated separately sensitivity to (a) PAN, (b) oVOCs (acetaldehyde, acetone) and (c) peroxides $\left(\mathrm{H}_{2} \mathrm{O}_{2}, \mathrm{CH}_{3} \mathrm{OOH}\right)$, using simulations where the initial concentrations of each of these three sets of species from each POLMIP model are decreased and increased by a factor of 2 . A factor 2 perturbation is consistent with inter-model differences and biases against observations for these species along the ARCTAS DC8 flight tracks (Emmons et al., 2014). We apply the same fractional perturbation to each species to directly compare sensitivities of Arctic ozone photochemistry to uncertainties in their abundances.

Ozone sensitivities to initial PAN concentration in the plume demonstrate the potential importance of model biases in Arctic $\mathrm{NO}_{y}$ for Arctic tropospheric ozone. Figure 14 shows changes in simulated ozone and $\mathrm{NO}_{x}$ evolution in the plume produced by simulations with perturbations to initial PAN. Increasing and decreasing initial PAN abundance in the plume leads to a reduction in $\mathrm{NO}_{x}$ and an increase in $\mathrm{NO}_{x}$, respectively (Fig. 14b). The consequent impacts on ozone change in the plume largely depend on the absolute $\mathrm{NO}_{x}$ concentration, and the magnitude of the $\mathrm{NO}_{x}$ perturbation brought about by the fractional change in initial PAN. In the TOMCAT, LMDZ-INCA and GMI-initialized plumes, an increase in initial PAN leads to a shift from slight net ozone loss to net ozone production of between 0.5 and $1 \mathrm{ppbv}$ over 4 days (Fig. 14b). Model plumes that descend over the 4 days have increased $\mathrm{NO}_{x}$ sensitivity to the PAN perturbation. Such altitude changes promote reduced PAN stability and release of $\mathrm{NO}_{2}$. This illustrates the potential sensitivity of in situ Arctic ozone production in the simulated fire 

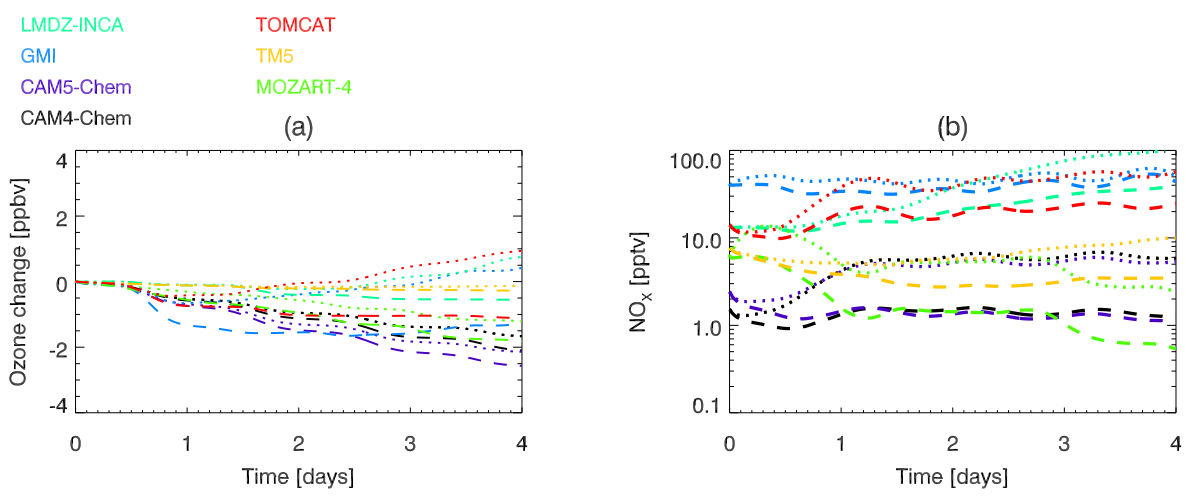

(c)

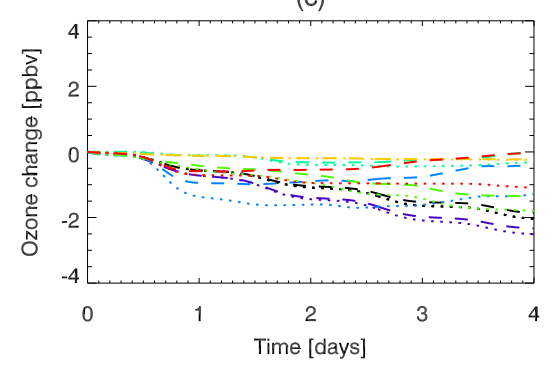

(d)

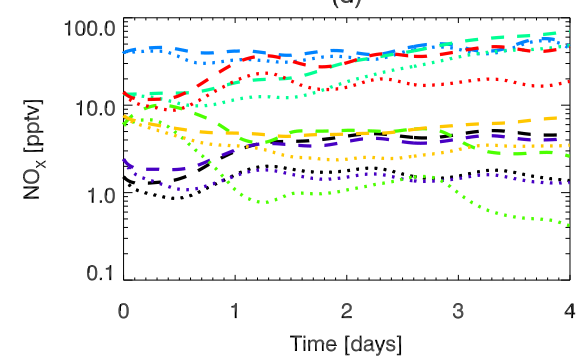

(e)

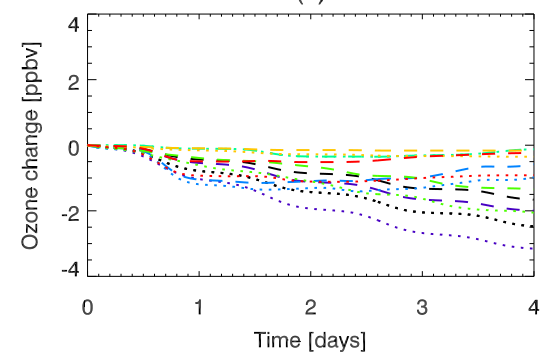

(f)

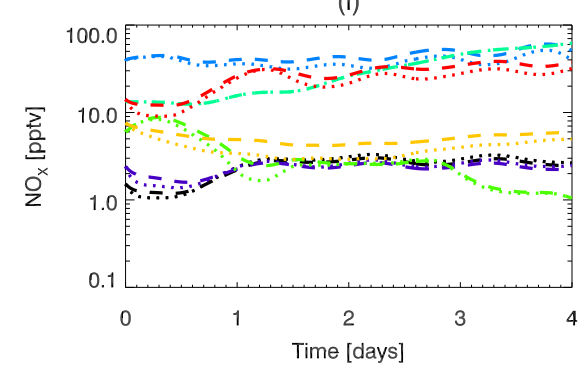

Figure 14. CiTTyCAT Lagrangian box model simulations showing sensitivity of fire plume ozone and $\mathrm{NO}_{x}$ evolution in the Arctic to initial concentrations of key species. Dotted and dashed lines show simulations initialized with 200 and $50 \%$, respectively, of PAN (a-b), acetone and acetaldehyde (c-d), $\mathrm{H}_{2} \mathrm{O}_{2}$ and $\mathrm{CH}_{3} \mathrm{OOH}(\mathbf{e}-\mathbf{f})$. Ozone change from simulations with unperturbed initial concentrations are shown in Fig. 12a.

plume to model $\mathrm{NO}_{y}$ partitioning errors. Increasing and decreasing initial oVOC abundances leads to enhancement and suppression of ozone loss in the plume respectively over the following 4 days (Fig. 14c and d), due to the role of acetaldehyde and acetone as a source of the peroxyacetyl radical during their photo-oxidation. This promotes the formation of PAN, reducing $\mathrm{NO}_{x}$ concentrations in the plume. Consequently, model plumes in which $\mathrm{NO}_{x}$ concentrations are large enough to promote ozone production show larger ozone sensitivity to this perturbation. These results suggest that after having undergone export from the continental boundary layer and long-range transport into the Arctic, PAN formation and loss may still play an important role in ozone photochemistry in such plumes. In plumes with very low $\mathrm{NO}_{x}$ abundances, and dominated by ozone loss, perturbation to initial peroxide concentrations produces a larger effect on ozone (approx. \pm 0.5 ppbv over 4 days in the CAM5-Chem plume) (Fig. 14e). Increased and decreased peroxide leads to increases and decreases in $\mathrm{HO}_{x}$ production from peroxide photolysis, resulting in changes to the rate of ozone loss via $\mathrm{O}_{3}+\mathrm{HO}_{2}$. Increased initial peroxide concentrations also lead to enhanced removal of $\mathrm{NO}_{x}$ in the plume, due to increased HOx production (Fig. 14f).

\section{Summary and conclusions}

We have evaluated tropospheric ozone enhancement in air dominated by biomass burning emissions at high latitudes $\left(>50^{\circ} \mathrm{N}\right)$ in the summer, using simulations from the POLMIP multi-model comparison exercise for July 2008. Using 25-day fixed-lifetime $\mathrm{CO}$ tracers emitted from fires and anthropogenic sources in the models, we calculated 
$\Delta \mathrm{O}_{3} / \Delta \mathrm{CO}$ enhancement ratios in air dominated by fire emissions. All POLMIP models that simulated fixed-lifetime tracers demonstrate positive ozone enhancement in firedominated air, with ozone enhancement increasing with air mass age on average in the models, suggesting net tropospheric ozone production in biomass burning air masses transported to the Arctic. $\Delta \mathrm{O}_{3} / \Delta \mathrm{CO}$ values ranged between 0.039 and $0.196 \mathrm{ppbv} \mathrm{ppbv}^{-1}$ (mean: $0.113 \mathrm{ppbv} \mathrm{ppbv}^{-1}$ ) in the younger air, and between 0.140 and $0.261 \mathrm{ppbv} \mathrm{ppbv}^{-1}$ (mean: $0.193 \mathrm{ppbv}$ ) in the more aged air, with age since emission defined by the ratio of propane to ethane mixing ratios. These values are in broad agreement with the range of observational estimates from the literature, and larger than those in some previous modelling studies. Model $\mathrm{NO}_{y}$ partitioning may play an important role in determining lower modeldiagnosed ozone production efficiencies.

Model $\triangle \mathrm{PAN} / \triangle \mathrm{CO}$ enhancement ratios at high latitudes show distinct groupings according to the meteorological data used to drive the models. ECMWF-forced models produce larger $\Delta \mathrm{PAN} / \Delta \mathrm{CO}$ values (4.44-6.28 $\mathrm{pptv} \mathrm{ppbv}^{-1}$ ) than GEOS5-forced models (2.02-3.02 $\mathrm{pptv} \mathrm{ppbv}^{-1}$ ), which we show is likely linked to differences in the efficiency of vertical transport during poleward export from mid-latitude source regions. Comparison with limited observations from the ARCTAS-B aircraft campaign suggests that the larger PAN enhancement ratios simulated by the ECMWF-forced models are consistent with the majority of these observations. We find little relationship between the efficiency of Arctic PAN import in fire-dominated air and Arctic ozone enhancement across the diverse range of POLMIP models.

All POLMIP models are capable of resolving a large plume of mixed Asian anthropogenic and Siberian fire pollution, which is imported to the Arctic on 7 July 2008, with close similarities in simulated horizontal structure. These features are in good agreement with $\mathrm{CO}$ observations from the IASI satellite instrument and the FLEXPART Lagrangian particle dispersion model, shown in a previous study (Sodemann et al., 2011). Fixed-lifetime tracers simulated by the models show that the leading edge of this plume is dominated by fire emissions in all POLMIP models. Simulations using a Lagrangian chemical transport model show that 4day net ozone change in the plume is sensitive to differences in plume chemical composition and plume vertical position among the POLMIP models. In particular, Arctic ozone evolution in the plume is highly sensitive to initial concentrations of PAN, as well as oxygenated VOCs (acetone, acetaldehyde), due to their role in producing the peroxyacetyl radical PAN precursor. Vertical displacement is also important due to its effects on the stability of PAN, and subsequent effect on $\mathrm{NO}_{x}$ abundance. In plumes where net ozone production is limited, we find that the lifetime of ozone in the plume is sensitive to hydrogen peroxide loading, due to the production of $\mathrm{HO}_{x}$ from peroxide photolysis, and the key role of $\mathrm{HO}_{2}+\mathrm{O}_{3}$ in controlling ozone loss.
Overall, our results suggest that emissions from biomass burning lead to large-scale enhancement in high-latitude $\mathrm{NO}_{y}$ and tropospheric ozone during summer, with increasing production of ozone as air masses age, and that this is consistent across a wide range of chemical transport models using the same emissions data. In addition, model deficiencies and inter-model differences in simulating species that are less commonly observed in the Arctic (PANs, oxygenated VOCs, and peroxides) are important to understand due to their substantial roles in governing in situ ozone production and loss in plumes imported to the summertime Arctic troposphere.

\section{The Supplement related to this article is available online at doi:10.5194/acp-15-6047-2015-supplement.}

Acknowledgements. S. R. Arnold acknowledges support from the NCAR Advanced Study Program via a Faculty Fellowship award, and the NCAR Atmospheric Chemistry Division. S. R. Arnold and S. A. Monks were supported by the EurEX project, funded by the UK Natural Environment Research Council (ref: NE/H020241/1). L. K. Emmons and S. Tilmes acknowledge the National Center for Atmospheric Research, which is sponsored by the US National Science Foundation. Author L. K. Emmons acknowledges support from the National Aeronautics and Space Administration under Award No. NNX08AD22G issued through the Science Mission Directorate, Tropospheric Composition Program. Authors K. S. Law, J. L. Thomas, S. Turquety and Y. Long acknowledge support from projects Agence National de Recherche (ANR) Climate Impact of Short-lived Climate Forcers and Methane in the Arctic (CLIMSLIP) Blanc SIMI 5-6 02101 and CLIMSLIP-LEFE (CNRS-INSU). V. Huijnen acknowledges funding from the European Union's Seventh Framework Programme (FP7) under Grant Agreement no. 283576. Contributions from the Swedish Meteorological and Hydrological Institute were funded by the Swedish Environmental Protection Agency under contract NV-09414-12 and through the Swedish Climate and Clean Air research programme, SCAC.

Edited by: T. Butler

\section{References}

Alvarado, M. J., Logan, J. A., Mao, J., Apel, E., Riemer, D., Blake, D., Cohen, R. C., Min, K.-E., Perring, A. E., Browne, E. C., Wooldridge, P. J., Diskin, G. S., Sachse, G. W., Fuelberg, H., Sessions, W. R., Harrigan, D. L., Huey, G., Liao, J., Case-Hanks, A., Jimenez, J. L., Cubison, M. J., Vay, S. A., Weinheimer, A. J., Knapp, D. J., Montzka, D. D., Flocke, F. M., Pollack, I. B., Wennberg, P. O., Kurten, A., Crounse, J., Clair, J. M. St., Wisthaler, A., Mikoviny, T., Yantosca, R. M., Carouge, C. C., and Le Sager, P.: Nitrogen oxides and PAN in plumes from boreal fires during ARCTAS-B and their impact on ozone: an integrated analysis of aircraft and satellite observations, Atmos. Chem. Phys., 10, 9739-9760, doi:10.5194/acp-10-9739-2010, 2010. 
Andreae, M. O., Browell, E. V., Garstang, M., Gregory, G. L., Harriss, R. C., Hill, G. F., Jacob, D. J., Pereira, M. C., Sachse, G. W., Setzer, A. W., Dias, P. L. S., Talbot, R. W., Torres, A. L., and Wofsy, S. C.: Biomass-burning emissions and associated haze layers over Amazonia, J. Geophys. Res.-Atmos., 93, 1509-1527, 1988.

Atkinson, R., Baulch, D. L., Cox, R. A., Crowley, J. N., Hampson, R. F., Hynes, R. G., Jenkin, M. E., Rossi, M. J., and Troe, J.: Evaluated kinetic and photochemical data for atmospheric chemistry: Volume $\mathrm{I}$ - gas phase reactions of $\mathrm{O}_{\mathrm{x}}, \mathrm{HO}_{\mathrm{x}}, \mathrm{NO}_{\mathrm{x}}$ and $\mathrm{SO}_{\mathrm{x}}$ species, Atmos. Chem. Phys., 4, 1461-1738, doi:10.5194/acp-41461-2004, 2004.

Atkinson, R., Baulch, D. L., Cox, R. A., Crowley, J. N., Hampson, R. F., Hynes, R. G., Jenkin, M. E., Rossi, M. J., Troe, J., and IUPAC Subcommittee: Evaluated kinetic and photochemical data for atmospheric chemistry: Volume II - gas phase reactions of organic species, Atmos. Chem. Phys., 6, 3625-4055, doi:10.5194/acp-6-3625-2006, 2006.

Bertschi, I. T., Jaffe, D. A. Jaeglé, L., Price, H. U., and Dennison, J. B.: PHOBEA/ITCT 2002 airborne observations of transpacific transport of ozone, $\mathrm{CO}$, volatile organic compounds, and aerosols to the northeast Pacific: Impacts of Asian anthropogenic and Siberian boreal fire emissions, J. Geophys. Res., 109, D23S12, doi:10.1029/2003JD004328, 2004.

Bonan, G. B.: Forests and Climate Change: Forcings, Feedbacks, and the Climate Benefits of Forests, Science, 320, 1444, doi:10.1126/science.1155121, 2008.

Bourgeois, Q. and Bey, I.: Pollution transport efficiency toward the Arctic: Sensitivity to aerosol scavenging and source regions, J. Geophys. Res., 116, D08213, doi:10.1029/2010JD015096, 2011.

Calvert, J. G.: Hydrocarbon involvement in photochemical smog formation in Los Angeles atmosphere, Environ. Sci. Technol., 10, 256-262, 1976.

Ciais, P., Sabine, C., Bala, G., Bopp, L., Brovkin, V., Canadell, J., Chhabra, A., DeFries, R., Galloway, J., Heimann, M., Jones, C., Le Quéré, C., Myneni, R. B., Piao, S., and Thornton, P.: Carbon and Other Biogeochemical Cycles, in: Climate Change 2013: The Physical Science Basis. Contribution of Working Group I to the Fifth Assessment Report of the Intergovernmental Panel on Climate Change, edited by: Stocker, T. F., Qin, D., Plattner, G.K., Tignor, M., Allen, S. K., Boschung, J., Nauels, A., Xia, Y., Bex, V., and Midgley, P. M., Cambridge University Press, Cambridge, United Kingdom and New York, NY, USA, 2013.

Crowley, J. N., Ammann, M., Cox, R. A., Hynes, R. G., Jenkin, M. E., Mellouki, A., Rossi, M. J., Troe, J., and Wallington, T. J.: Evaluated kinetic and photochemical data for atmospheric chemistry: Volume V - heterogeneous reactions on solid substrates, Atmos. Chem. Phys., 10, 9059-9223, doi:10.5194/acp-10-90592010, 2010.

de Groot, W. J., Flannigan, M. D., and Cantin, A. S.: Climate change impacts on future boreal fire regimes, For. Ecol. Manage., 294, 35-44, 2013.

Emmons, L. K., Arnold, S. R., Monks, S. A., Huijnen, V., Tilmes, S., Law, K. S., Thomas, J. L., Raut, J.-C., Bouarar, I., Turquety, S., Long, Y., Duncan, B., Steenrod, S., Strode, S., Flemming, J., Mao, J., Langner, J., Thompson, A. M., Tarasick, D., Apel, E. C., Blake, D. R., Cohen, R. C., Dibb, J., Diskin, G. S., Fried, A., Hall, S. R., Huey, L. G., Weinheimer, A. J., Wisthaler, A., Mikoviny, T., Nowak, J., Peischl, J., Roberts, J. M., Ryerson,
T., Warneke, C., and Helmig, D.: The POLARCAT Model Intercomparison Project (POLMIP): overview and evaluation with observations, Atmos. Chem. Phys. Discuss., 14, 29331-29393, doi:10.5194/acpd-14-29331-2014, 2014.

Fischer, E. V., Jacob, D. J., Yantosca, R. M., Sulprizio, M. P., Millet, D. B., Mao, J., Paulot, F., Singh, H. B., Roiger, A., Ries, L., Talbot, R. W., Dzepina, K., and Pandey Deolal, S.: Atmospheric peroxyacetyl nitrate (PAN): a global budget and source attribution, Atmos. Chem. Phys., 14, 2679-2698, doi:10.5194/acp-142679-2014, 2014.

Fisher, J. A., Jacob, D. J., Purdy, M. T., Kopacz, M., Le Sager, P., Carouge, C., Holmes, C. D., Yantosca, R. M., Batchelor, R. L., Strong, K., Diskin, G. S., Fuelberg, H. E., Holloway, J. S., Hyer, E. J., McMillan, W. W., Warner, J., Streets, D. G., Zhang, Q., Wang, Y., and Wu, S.: Source attribution and interannual variability of Arctic pollution in spring constrained by aircraft (ARCTAS, ARCPAC) and satellite (AIRS) observations of carbon monoxide, Atmos. Chem. Phys., 10, 977-996, doi:10.5194/acp10-977-2010, 2010.

Goode, J. G., Yokelson, R. J., Ward, D. E., Susott, R. A., Babbitt, R. E., Davies, M. A., and Hao, W. M.: Measurements of excess $\mathrm{O}_{3}, \mathrm{CO}_{2}, \mathrm{CO}, \mathrm{CH}_{4}, \mathrm{C}_{2} \mathrm{H}_{4}, \mathrm{C}_{2} \mathrm{H}_{2}, \mathrm{HCN}, \mathrm{NO}, \mathrm{NH}_{3}$, $\mathrm{HCOOH}, \mathrm{CH}_{3} \mathrm{COOH}, \mathrm{HCHO}$, and $\mathrm{CH}_{3} \mathrm{OH}$ in 1997 Alaskan biomass burning plumes by airborne fourier transform infrared spectroscopy (AFTIR), J. Geophys. Res.-Atmos., 105, 22147 22166, 2000.

Honrath, R. E., Owen, R. C., ValMartin, M., Reid, J. S., Lapina, K., Fialho, P., Dziobak, M. P., Kleissl, J., and Westphal, D. L.: Regional and hemispheric impacts of anthropogenic and biomass burning emissions on summertime $\mathrm{CO}$ and $\mathrm{O}_{3}$ in the North Atlantic lower free troposphere, J. Geophys. Res., 109, D24310, doi:10.1029/2004JD005147, 2004.

Hornbrook, R. S., Blake, D. R., Diskin, G. S., Fried, A., Fuelberg, H. E., Meinardi, S., Mikoviny, T., Richter, D., Sachse, G. W., Vay, S. A., Walega, J., Weibring, P., Weinheimer, A. J., Wiedinmyer, C., Wisthaler, A., Hills, A., Riemer, D. D., and Apel, E. C.: Observations of nonmethane organic compounds during ARCTAS - Part 1: Biomass burning emissions and plume enhancements, Atmos. Chem. Phys., 11, 11103-11130, doi:10.5194/acp11-11103-2011, 2011.

Jacob, D. J., Wofsy, S. C., Bakwin, P. S., Fan, S. M., Harriss, R. C., Talbot, R. W., Bradshaw, J. D., Sandholm, S. T., Singh, H. B., Browell, E. V., Gregory, G. L., Sachse, G. W., Shipham, M. C., Blake, D. R., and Fitzjarrald, D. R.: Summertime photochemistry of the troposphere at high northern latitudes, J. Geophys. Res.Atmos., 97, 16421-16431, 1992.

Jacob, D. J., Crawford, J. H., Maring, H., Clarke, A. D., Dibb, J. E., Emmons, L. K., Ferrare, R. A., Hostetler, C. A., Russell, P. B., Singh, H. B., Thompson, A. M., Shaw, G. E., McCauley, E., Pederson, J. R., and Fisher, J. A.: The Arctic Research of the Composition of the Troposphere from Aircraft and Satellites (ARCTAS) mission: design, execution, and first results, Atmos. Chem. Phys., 10, 5191-5212, doi:10.5194/acp-10-5191-2010, 2010.

Jaffe, D. A. and Wigder, N. L.: Ozone production from wildfires: A critical review, Atmos. Environ., 51, 1-10, 2012.

Lamarque, J.-F., Bond, T. C., Eyring, V., Granier, C., Heil, A., Klimont, Z., Lee, D., Liousse, C., Mieville, A., Owen, B., Schultz, M. G., Shindell, D., Smith, S. J., Stehfest, E., Van Aardenne, J., Cooper, O. R., Kainuma, M., Mahowald, N., Mc- 
Connell, J. R., Naik, V., Riahi, K., and van Vuuren, D. P.: Historical (1850-2000) gridded anthropogenic and biomass burning emissions of reactive gases and aerosols: methodology and application, Atmos. Chem. Phys., 10, 7017-7039, doi:10.5194/acp10-7017-2010, 2010.

Law, K. S., Stohl, A., Quinn, P. K., Brock, C., Burkhart, J., Paris, J.-D., Ancellet, G., Singh, H. B., Roiger, A., Schlager, H., Dibb, J., Jacob, D. J., Arnold, S. R., Pelon, J., and Thomas, J. L., Arctic Air Pollution: New Insights from POLARCAT-IPY, B. Am. Meteorol. Soc., 95, 1873-1895, doi:10.1175/BAMS-D-13-00017.1, 2014.

Liang, Q., Rodriguez, J. M., Douglass, A. R., Crawford, J. H., Olson, J. R., Apel, E., Bian, H., Blake, D. R., Brune, W., Chin, M., Colarco, P. R., da Silva, A., Diskin, G. S., Duncan, B. N., Huey, L. G., Knapp, D. J., Montzka, D. D., Nielsen, J. E., Pawson, S., Riemer, D. D., Weinheimer, A. J., and Wisthaler, A.: Reactive nitrogen, ozone and ozone production in the Arctic troposphere and the impact of stratosphere-troposphere exchange, Atmos. Chem. Phys., 11, 13181-13199, doi:10.5194/acp-11-13181-2011, 2011.

Mao, J., Fan, S., Jacob, D. J., and Travis, K. R.: Radical loss in the atmosphere from $\mathrm{Cu}-\mathrm{Fe}$ redox coupling in aerosols, Atmos. Chem. Phys., 13, 509-519, doi:10.5194/acp-13-509-2013, 2013a.

Mao, J. Q., Horowitz, L. W., Naik, V., Fan, S. M., Liu, J. F., and Fiore, A. M.: Sensitivity of tropospheric oxidants to biomass burning emissions: implications for radiative forcing, Geophys. Res. Lett., 40, 1241-1246, 2013 b.

Mauzerall, D. L., Jacob, D. J., Fan, S. M., Bradshaw, J. D., Gregory, G. L., Sachse, G. W., and Blake, D. R.: Origin of tropospheric ozone at remote high northern latitudes in summer, J. Geophys. Res.-Atmos., 101, 4175-4188, 1996.

Methven, J., Arnold, S. R., O'Connor, F. M., Barjat, H., Dewey, K., Kent, J., and Brough, N.: Estimating photochemically produced ozone throughout a domain using flight data and a Lagrangian model, J. Geophys. Res., 108, 4271, doi:10.1029/2002JD002955, 2003.

Monks, S. A., Arnold, S. R., and Chipperfield, M. P.: Evidence for El Niño - Southern Oscillation (ENSO) influence on Arctic CO interannual variability through biomass burning emissions, Geophys. Res. Lett., 39, L14804, doi:10.1029/2012GL052512, 2012.

Monks, S. A., Arnold, S. R., Emmons, L. K., Law, K. S., Turquety, S., Duncan, B. N., Flemming, J., Huijnen, V., Tilmes, S., Langner, J., Mao, J., Long, Y., Thomas, J. L., Steenrod, S. D., Raut, J. C., Wilson, C., Chipperfield, M. P., Diskin, G. S., Weinheimer, A., Schlager, H., and Ancellet, G.: Multi-model study of chemical and physical controls on transport of anthropogenic and biomass burning pollution to the Arctic, Atmos. Chem. Phys., 15, 3575-3603, doi:10.5194/acp-15-3575-2015, 2015.

Naik, V., Voulgarakis, A., Fiore, A. M., Horowitz, L. W., Lamarque, J.-F., Lin, M., Prather, M. J., Young, P. J., Bergmann, D., Cameron-Smith, P. J., Cionni, I., Collins, W. J., Dalsøren, S. B., Doherty, R., Eyring, V., Faluvegi, G., Folberth, G. A., Josse, B., Lee, Y. H., MacKenzie, I. A., Nagashima, T., van Noije, T. P. C., Plummer, D. A., Righi, M., Rumbold, S. T., Skeie, R., Shindell, D. T., Stevenson, D. S., Strode, S., Sudo, K., Szopa, S., and Zeng, G.: Preindustrial to present-day changes in tropospheric hydroxyl radical and methane lifetime from the Atmospheric Chemistry and Climate Model Intercomparison Project (ACCMIP), Atmos.
Chem. Phys., 13, 5277-5298, doi:10.5194/acp-13-5277-2013, 2013.

Olson, J. R., Crawford, J. H., Brune, W., Mao, J., Ren, X., Fried, A., Anderson, B., Apel, E., Beaver, M., Blake, D., Chen, G., Crounse, J., Dibb, J., Diskin, G., Hall, S. R., Huey, L. G., Knapp, D., Richter, D., Riemer, D., Clair, J. St., Ullmann, K., Walega, J., Weibring, P., Weinheimer, A., Wennberg, P., and Wisthaler, A.: An analysis of fast photochemistry over high northern latitudes during spring and summer using in-situ observations from ARCTAS and TOPSE, Atmos. Chem. Phys., 12, 6799-6825, doi:10.5194/acp-12-6799-2012, 2012.

Paris, J.-D., Stohl, A., Nédélec, P., Arshinov, M. Yu., Panchenko, M. V., Shmargunov, V. P., Law, K. S., Belan, B. D., and Ciais, P. Wildfire smoke in the Siberian Arctic in summer: source characterization and plume evolution from airborne measurements, Atmos. Chem. Phys., 9, 9315-9327, doi:10.5194/acp-9-9315-2009, 2009.

Parrella, J. P., Jacob, D. J., Liang, Q., Zhang, Y., Mickley, L. J., Miller, B., Evans, M. J., Yang, X., Pyle, J. A., Theys, N., and Van Roozendael, M.: Tropospheric bromine chemistry: implications for present and pre-industrial ozone and mercury, Atmos. Chem. Phys., 12, 6723-6740, doi:10.5194/acp-12-6723-2012, 2012.

Parrington, M., Palmer, P. I., Henze, D. K., Tarasick, D. W., Hyer, E. J., Owen, R. C., Helmig, D., Clerbaux, C., Bowman, K. W., Deeter, M. N., Barratt, E. M., Coheur, P.-F., Hurtmans, D., Jiang, Z., George, M., and Worden, J. R.: The influence of boreal biomass burning emissions on the distribution of tropospheric ozone over North America and the North Atlantic during 2010, Atmos. Chem. Phys., 12, 2077-2098, doi:10.5194/acp-12-20772012, 2012.

Parrington, M., Palmer, P. I., Lewis, A. C., Lee, J. D., Rickard, A. R., Di Carlo, P., Taylor, J. W., Hopkins, J. R., Punjabi, S., Oram, D. E., Forster, G., Aruffo, E., Moller, S. J., Bauguitte, S. J.-B., Allan, J. D., Coe, H., and Leigh, R. J.: Ozone photochemistry in boreal biomass burning plumes, Atmos. Chem. Phys., 13, 73217341, doi:10.5194/acp-13-7321-2013, 2013.

Pfister, G. G., Emmons, L. K., Hess, P. G., Honrath, R., Lamarque, J. F., Martin, M. V., Owen, R. C., Avery, M. A., Browell, E. V., Holloway, J. S., Nedelec, P., Purvis, R., Ryerson, T. B., Sachse, G. W., and Schlager, H.: Ozone production from the 2004 North American boreal fires, J. Geophys. Res., 111, D24S07, doi:10.1029/2006JD007695, 2006.

Pommier, M., Law, K. S., Clerbaux, C., Turquety, S., Hurtmans, D., Hadji-Lazaro, J., Coheur, P.-F., Schlager, H., Ancellet, G., Paris, J.-D., Nédélec, P., Diskin, G. S., Podolske, J. R., Holloway, J. S., and Bernath, P.: IASI carbon monoxide validation over the Arctic during POLARCAT spring and summer campaigns, Atmos. Chem. Phys., 10, 10655-10678, doi:10.5194/acp-1010655-2010, 2010.

Pugh, T. A. M., Cain, M., Methven, J., Wild, O., Arnold, S. R., Real, E., Law, K. S., Emmerson, K. M., Owen, S. M., Pyle, J. A., Hewitt, C. N., and MacKenzie, A. R.: A Lagrangian model of air-mass photochemistry and mixing using a trajectory ensemble: the Cambridge Tropospheric Trajectory model of Chemistry And Transport (CiTTyCAT) version 4.2, Geosci. Model Dev., 5, 193 221, doi:10.5194/gmd-5-193-2012, 2012.

Quinn, P. K., Bates, T. S., Baum, E., Doubleday, N., Fiore, A. M., Flanner, M., Fridlind, A., Garrett, T. J., Koch, D., Menon, S., Shindell, D., Stohl, A., and Warren, S. G.: Short-lived pollu- 
tants in the Arctic: their climate impact and possible mitigation strategies, Atmos. Chem. Phys., 8, 1723-1735, doi:10.5194/acp8-1723-2008, 2008.

Real, E., Law, K. S., Wienzierl, B., Fiebig, M., Petzold, A., Wild, O., Methven, J., Arnold, S. R., Stohl, A., Huntrieser, H., Roiger, A., Schlager, H., Stewart, D., Avery, M., Sachse, G., Browell, E., Ferrare, R., and Blake, D.: Processes influencing ozone levels in Alaskan forest fire plumes during long-range transport over the North Atlantic, J. Geophys. Res., 112, D10S41, doi:10.1029/2006JD007576, 2007.

Roiger, A., Schlager, H., Schäfler, A., Huntrieser, H., Scheibe, M., Aufmhoff, H., Cooper, O. R., Sodemann, H., Stohl, A., Burkhart, J., Lazzara, M., Schiller, C., Law, K. S., and Arnold, F.: Insitu observation of Asian pollution transported into the Arctic lowermost stratosphere, Atmos. Chem. Phys., 11, 10975-10994, doi:10.5194/acp-11-10975-2011, 2011.

Sander, S. P., Abbatt, J., Barker, J. R., Burkholder, J. B., Friedl, R. R., Golden, D. M., Huie, R. E., Kolb, C. E., Kurylo, M. J., Moortgat, G. K., Orkin, V. L., and Wine, P. H.: Chemical Kinetics and Photochemical Data for Use in Atmospheric, Studies Evaluation Number 17, JPL Publication 10-6, available at: http://jpldataeval.jpl.nasa.gov (last access: 2 June 2015), Jet Propulsion Laboratory, Pasadena, 2011.

Shindell, D.: Local and remote contributions to Arctic warming, Geophys. Res. Lett., 34, L14704, doi:10.1029/2007GL030221, 2007.

Shindell, D. and Faluvegi, G.: Climate response to regional radiative forcing during the twentieth century, Nat. Geosci., 2, 294-300, 2009.

Shindell, D. T., Chin, M., Dentener, F., Doherty, R. M., Faluvegi, G., Fiore, A. M., Hess, P., Koch, D. M., MacKenzie, I. A., Sanderson, M. G., Schultz, M. G., Schulz, M., Stevenson, D. S., Teich, H., Textor, C., Wild, O., Bergmann, D. J., Bey, I., Bian, H., Cuvelier, C., Duncan, B. N., Folberth, G., Horowitz, L. W., Jonson, J., Kaminski, J. W., Marmer, E., Park, R., Pringle, K. J., Schroeder, S., Szopa, S., Takemura, T., Zeng, G., Keating, T. J., and Zuber, A.: A multi-model assessment of pollution transport to the Arctic, Atmos. Chem. Phys., 8, 5353-5372, doi:10.5194/acp-85353-2008, 2008.

Singh, H. B. and Hanst, P. L.: Peroxyacetyl nitrate (PAN) in the unpolluted atmosphere - an important reservoir for nitrogenoxides, Geophys. Res. Lett., 8, 941-944, 1981.

Singh, H. B., O'Hara, D., Herlth, D., Bradshaw, J. D., Sandholm, S. T., Gregory, G. L., Sachse, G. W., Blake, D. R., Crutzen, P. J., and Kanakidou, M. A.: Atmospheric measurements of peroxyacetyl nitrate and other organic nitrates at high latitudes: Possible sources and sinks, J. Geophys. Res.-Atmos., 97, 16511-16522, 1992.

Singh, H. B., Anderson, B. E., Brune, W. H., Cai, C., Cohen, R. C., Crawford, J. H., Cubison, M. J., Czech, E. P., Emmons, L., Fuelberg, H. E., Huey, G., Jacob, D. J., Jimenez, J. L., Kaduwela, A., Kondo, Y., Mao, J., Olson, J. R., Sachse, G. W., Vay, S. A., Weinheimer, A., Wennberg, P. O., Wisthaler, A., and Team, A. S.: Pollution influences on atmospheric composition and chemistry at high northern latitudes: Boreal and California forest fire emissions, Atmos. Environ., 44, 4553-4564, 2010.

Sodemann, H., Pommier, M., Arnold, S. R., Monks, S. A., Stebel, K., Burkhart, J. F., Hair, J. W., Diskin, G. S., Clerbaux, C., Coheur, P.-F., Hurtmans, D., Schlager, H., Blechschmidt, A.-M.,
Kristjánsson, J. E., and Stohl, A.: Episodes of cross-polar transport in the Arctic troposphere during July 2008 as seen from models, satellite, and aircraft observations, Atmos. Chem. Phys., 11, 3631-3651, doi:10.5194/acp-11-3631-2011, 2011.

Tanimoto, H., Matsumoto, K., and Uematsu, M.: Ozone-CO Correlations in Siberian Wildfire Plumes Observed at Rishiri Island, Sola, 4, 65-68, 2008.

Thomas, J. L., Raut, J.-C., Law, K. S., Marelle, L., Ancellet, G., Ravetta, F., Fast, J. D., Pfister, G., Emmons, L. K., Diskin, G. S., Weinheimer, A., Roiger, A., and Schlager, H.: Pollution transport from North America to Greenland during summer 2008, Atmos. Chem. Phys., 13, 3825-3848, doi:10.5194/acp-13-38252013, 2013.

Val Martin, M. R., Honrath, R. E., Owen, R. C., Pfister, G., Fialho, P., and Barata, F.: Significant enhancements of nitrogen oxides, ozone and aerosol black carbon in the North Atlantic lower free troposphere resulting from North American boreal wildfires, J. Geophys. Res., 111, D23S60, doi:10.1029/2006JD007530, 2006. van der Werf, G. R., Randerson, J. T., Giglio, L., Collatz, G. J., Mu, M., Kasibhatla, P. S., Morton, D. C., DeFries, R. S., Jin, Y., and van Leeuwen, T. T.: Global fire emissions and the contribution of deforestation, savanna, forest, agricultural, and peat fires (19972009), Atmos. Chem. Phys., 10, 11707-11735, doi:10.5194/acp10-11707-2010, 2010.

Voulgarakis, A., Telford, P. J., Aghedo, A. M., Braesicke, P., Faluvegi, G., Abraham, N. L., Bowman, K. W., Pyle, J. A., and Shindell, D. T.: Global multi-year $\mathrm{O}_{3}-\mathrm{CO}$ correlation patterns from models and TES satellite observations, Atmos. Chem. Phys., 11, 5819-5838, doi:10.5194/acp-11-5819-2011, 2011.

Walker, T. W., Jones, D. B. A., Parrington, M., Henze, D. K., Murray, L. T., Bottenheim, J. W., Anlauf, K., Worden, J. R., Bowman, K. W., Shim, C., Singh, K., Kopacz, M., Tarasick, D. W., Davies, J., von der Gathen, P., Thompson, A. M., and Carouge, C. C.: Impacts of midlatitude precursor emissions and local photochemistry on ozone abundances in the Arctic, J. Geophys. Res., 117, D01305, doi:10.1029/2011JD016370, 2012.

Warneke, C., Froyd, K. D., Brioude, J., Bahreini, R., Brock, C. A., Cozic, J., de Gouw, J. A., Fahey, D. W., Ferrare, R., Holloway, J. S., Middlebrook, A. M., Miller, L., Montzka, S., Schwarz, J. P., Sodemann, H., Spackman, J. R., and Stohl, A.: An important contribution to springtime Arctic aerosol from biomass burning in Russia, Geophys. Res. Lett., 37, L01801, doi:10.1029/2009GL041816, 2010.

Wespes, C., Emmons, L., Edwards, D. P., Hannigan, J., Hurtmans, D., Saunois, M., Coheur, P.-F., Clerbaux, C., Coffey, M. T., Batchelor, R. L., Lindenmaier, R., Strong, K., Weinheimer, A. J., Nowak, J. B., Ryerson, T. B., Crounse, J. D., and Wennberg, P. O.: Analysis of ozone and nitric acid in spring and summer Arctic pollution using aircraft, ground-based, satellite observations and MOZART-4 model: source attribution and partitioning, Atmos. Chem. Phys., 12, 237-259, doi:10.5194/acp-12-237-2012, 2012.

Wiedinmyer, C., Akagi, S. K., Yokelson, R. J., Emmons, L. K., AlSaadi, J. A., Orlando, J. J., and Soja, A. J.: The Fire INventory from NCAR (FINN): a high resolution global model to estimate the emissions from open burning, Geosci. Model Dev., 4, 625641, doi:10.5194/gmd-4-625-2011, 2011.

Wofsy, S. C., Sachse, G. W., Gregory, G. L., Blake, D. R., Bradshaw, J. D., Sandholm, S. T., Singh, H. B., Barrick, J. A., Harriss, R. C., 
Talbot, R. W., Shipham, M. A., Browell, E. V., Jacob, D. J., and Logan, J. A.: Atmospheric chemistry in the Arctic and sub-Arctic - influence of natural fires, industrial emissions and stratospheric inputs, J. Geophys. Res.-Atmo., 97, 16731-16746, 1992.
Zhang, B., Owen, R. C., Perlinger, J. A., Kumar, A., Wu, S., Val Martin, M., Kramer, L., Helmig, D., and Honrath, R. E.: A semiLagrangian view of ozone production tendency in North American outflow in the summers of 2009 and 2010, Atmos. Chem. Phys., 14, 2267-2287, doi:10.5194/acp-14-2267-2014, 2014. 